\title{
A importância da ação individual e dos processos de socialização no combate às alterações climáticas de origem antrópica ${ }^{1}$
}

\author{
The significance of individual action and the socialization processes in the fight against anthropogenic climate change ${ }^{2}$
}

\author{
Marco Pais Neves dos Santos'
}

'Doutorando em Sustentabilidade Social e Desenvolvimento, Universidade Aberta, Lisboa, Portugal.

\begin{abstract}
Resumo
O presente ensaio, de base monográfica subordinado ao tema da sociologia das alterações climáticas no contexto da vida é sobretudo um exercício de reflexão sobre como o comportamento pessoal e as oportunidades de vida são influenciadas pelas estruturas da sociedade em que vivemos. No início, para contextualização, introduzimos a problemáticas das alterações climáticas. Segue-se o núcleo central do trabalho, estruturado em duas áreas: uma primeira, mais teórica, sobre a importância dos processos de socialização para o desenvolvimento social e ambiental, e para as questões das alterações climáticas, grande problemática ambiental do século XXI e, uma segunda, com base num estudo de caso, a própria vida do autor, refletimos sobre o poder que este sente deter no interior do conjunto das estruturas em que se movimenta, e que lhe são próprias, e na ação individual que considera possível exercer no seio dessas estruturas sociais. Conclui-se que a sua interação com a estrutura, e a sua ação individual, têm influenciado a atitude dos que o rodeiam face às alterações climáticas, o que significa que é possível um mundo melhor, e que tudo depende de nós próprios (da nossa agência).
\end{abstract}

Palavras-chaves: Cidadania Ambiental e Participação; Sustentabilidade; Alterações Climáticas; Contextos da Vida.

\begin{abstract}
This monograph-based paper on the sociology of climate change in the context of life experiences is mostly a reflection exercise on how individual behaviour and life opportunities are affected by the structures of the society we live in. To place this in context, we start with an introduction to climate change issues. We then present the main focus of our work, which is divided into two parts: the first one is more theoretical and examines the significance of the socialisation processes for the social and environmental development and for climate change issues, a major environmental concern in the 21st century; the second one is based on a case study - the author's own life - and reflects upon the power he feels he has within the structures he moves in, and of his own, as well as on the individual influence he thinks he can have within these social structures. We come to the conclusion that his interaction with the social structure and his individual action as regards climate change have been influential in the attitudes of people around him, which means that the world can be better and everything depends on us (on our agency).
\end{abstract}

Keywords: Environmental citizenship and participation; Sustainability; Climate change; Life contexts.

\footnotetext{
${ }^{1}$ Trabalho realizado no âmbito do IMOOC "Alterações Climáticas: o contexto das experiências de vida", na Universidade Aberta de Portugal, entre 14 de maio de 2013 e 1 de julho de 2013, para efeitos de avaliação do Tópico 4. "A perspetiva sociológica sobre a alteração climática". ${ }^{2}$ This study was carried out within the scope of iMOOC "Climate Changes: The Context of Life Experiences", organized by the Universidade Aberta, Portugal, from 14 May 2013 to 1 July 2013, for assessment purposes under Topic 4 "The sociological perspective on climate change".
} 


\section{AS ALTERAÇÕES CLIMÁTICAS: UMA CONTEXTUALIZAÇÃO}

O clima da Terra ${ }^{3}$, considerado estável à escala histórica, sofreu intensas variações à escala geológica (BAUD et al., 1999, p. 54), e essas evidências chegam da paleoclimatologia (HOTZ, 2010), da paleontologia, da dendrocronologia, entre outras. Foi no Quaternário, período de evolução e dispersão da espécie humana (BOYD e SILK, 2006), também um período de mudanças climáticas de grande impacto, que ocorreram na Terra diversos episódios de arrefecimento e aquecimento (alternância de períodos glaciários e interglaciários). O Holocénico, que chegou até hoje, é considerado o último período interglaciário do Quaternário. Não obstante, nas variações climáticas mais recentes, considera-se uma "pequena era glaciária" o período entre 1550 e 1850.

"O quaternário foi marcado por uma alternância de períodos glaciários e períodos interglaciários cujo sincronismo planetário é notável. Quanto às variações recentes, têm sido estudadas principalmente pelos historiadores que identificaram, desde há 1000 anos, períodos mais quentes - o século XI, por volta de 1750 e cerca de 1850 - alternando com períodos de frio mais intenso - o século XIII e sobretudo o período que vai de 1550 a 1850, chamado "pequena era glaciária"” (BAUD et al., 1999, p. 65-66).

Quando analisamos dados climatológicos de um longo período de tempo, percebemos que as alterações climáticas sempre existiram na vida do planeta, há mais de 4600 milhões de anos, até com alguma previsibilidade, causadas por fatores naturais como a variação na inclinação do eixo terrestre, a variação da excentricidade da órbita terreste em volta do sol, os ciclos solares, a precessão do eixo de rotação terrestre, a queda de meteoritos e o vulcanismo ${ }^{4}$. É, por isso, importante distinguir variações climáticas de baixa amplitude de variações climáticas de elevado impacto, como foram as quaternárias, e também distinguir variações longínquas, produzidas por fatores naturais, de alterações recentes do clima, produzidas por fatores humanos, e potenciais causas.

“[...] sabe-se que houve uma alternância entre épocas glaciares e períodos mais quentes e que as temperaturas na Terra oscilaram entre $9^{\circ}$ e $22^{\circ} \mathrm{C}$ (a temperatura média mundial é actualmente de $15^{\circ} \mathrm{C}$ ). Estas oscilações deveram-se a causas naturais, como variações na órbita da Terra à volta do Sol e no eixo da Terra, alterações na actividade solar e erupções vulcânicas" (COMISSÃO EUROPEIA, 2006, p. 10).

Se durante milhares de anos as alterações climáticas aconteceram de forma lenta, associadas a causas naturais, desde a Revolução Industrial que a humanidade tem acelerado a tendência de subida da temperatura ${ }^{5}$, que já existia desde o fim da última glaciação, pelo aumento de emissões de gases com efeito de estufa (GEE), cuja presença na atmosfera está a aumentar muito rapidamente devido às atividades humanas. Ou seja, o que agora está em causa é existirem alterações climáticas de origem antropogénica, induzidas pela nossa ação, isto é, trata-se da nossa ação como causadora de uma mudança climática, de forma muito célere (ou pelo menos a uma velocidade superior à alteração verificada pela ação da natureza), e com implicações novas, que não podemos comparar com outros períodos da história do clima, porque só agora a nossa população atingiu um grande número, e está a ter cada vez mais práticas excessivas, fazendo desta uma crise planetária.

No entanto, só no segundo quartel do século XX, numa comunicação apresentada à Royal Meteorological Society de Londres (1938), é que, pela primeira vez, um cientista teve a audácia de

\footnotetext{
3 Os climas da Terra são muito diversificados, e podem ser explicados pela latitude, continentalidade e altitude. Para caracterizar um clima importam as características médias da atmosfera num determinado lugar durante um longo período.

4 Enquanto fator natural das alterações climáticas, o vulcanismo tem sido contestado por alguns cientistas, considerando que: (i) as partículas do pó vulcânico são demasiado grandes para absorver a radiação; (ii) as poeiras teriam de permanecer muito tempo em suspensão, o que não é espectável que aconteça, para fazer aumentar a temperatura da Terra. No entanto, considerámos que "volcanic eruptions cause short-term climate changes and contribute to natural climate variability", como refere Georgiy Stenchikov, professor e investigador do Departamento de Ciências Ambientais da Universidade de Rutgers (STENCHIKOV et al., 1998; KIRCHNER et al., 1999).
}

5 Nos últimos 10 mil anos o clima esteve estável em torno de $1^{\circ} \mathrm{C}$. Os governos fixaram a barreira de subida no máximo de $2^{\circ} \mathrm{C}$. No entanto, para este século, alguns cientistas apontam $3^{\circ} \mathrm{C}$ (ROBERTS, 2012). 
estabelecer uma relação de causa e efeito entre as atividades humanas e o clima. O engenheiro Guy Stewart Callendar afirmou que "o aumento da temperatura média global observado desde o início do século XX era resultante das emissões de $\mathrm{CO}_{2}$ para a atmosfera provocadas pela combustão dos combustíveis fósseis - carvão, petróleo e gás natural (...). O artigo de Callendar foi recebido com grande ceticismo e praticamente esquecido"(SANTOS, 2007, p. 49).

Nos anos 70, e apesar de o Eng. Callendar ter levantado a questão na década de $40^{6}$, o conhecimento nesta matéria ainda era reduzido, o que se deve à pouca informação, pouco estudo, e pouco financiamento. Era um assunto que ainda não tinha conquistado espaço de excelência entre a academia.

Só nos anos 80 , na posse de provas suficientes, é que vários governos consideraram a subida da temperatura do planeta como uma ameaça à economia (COMISSÃO EUROPEIA, 2006, p. 12). Sabe-se, desde essa altura, que as fontes/atividades humanas que mais libertam GEE na atmosfera, cujas concentrações levam ao efeito de estufa, contribuindo para o aquecimento do clima, são: a queima de combustíveis fósseis (carvão, petróleo e gás) na produção de eletricidade, nos transportes, na indústria e em utilizações domésticas $\left(\mathrm{CO}_{2}\right)$; a agricultura $\left(\mathrm{CH}_{4)}\right.$ e as alterações da utilização dos solos, por via de queimadas descontroladas e desflorestação $\left(\mathrm{CO}_{2}\right)$; os aterros sanitários $\left(\mathrm{CH}_{4}\right)$; e a utilização de gases industriais fluorados.

Os países perceberam que este era um problema mundial, em vários níveis, desde logo pela transversalidade, mas também porque todos os países eram potenciais contribuidores e recebedores de consequências, em tempo e espaço diferentes, mas nenhum poderia resolver o problema de forma unilateral e isolada.

Formalizou-se um acordo internacional aceite por 189 países, considerando responsabilidades comuns mas diferenciadas, que contribuiu amplamente para a criação de linhas orientadoras e princípios-chave para a luta internacional contra as alterações climáticas: a Convenção Quadro das Nações Unidas sobre as Alterações Climáticas (United Nations framework Convention on Climate Change) (UNFCCC) ${ }^{7}$, adotada em Nova Iorque, em 9 de maio de 1992.

A definição de alterações climáticas, produzida pela Convenção-Quadro, distingue claramente alterações climáticas de natureza antrópica, capazes de alterar a composição da atmosfera, da variabilidade climática resultante de causas naturais. No n. ${ }^{\circ} 2$ do artigo $1 .^{\circ}$ do texto da Convenção, pode ler-se que as alterações climáticas "resultam de uma mudança do clima atribuída diretamente ou indiretamente à atividade humana, que altera a composição global da atmosfera e que, conjugada com as variações climáticas naturais, é observada durante períodos de tempo comparáveis" (UNFCCC, 1992, p. 7).

O Painel Intergovernamental sobre Mudanças Climáticas (The Intergovernmental Panel on Climate Change) (IPCC), numa outra perspetiva complementar, refere que estamos perante alterações climáticas quando existe "variação estatisticamente significativa (no mínimo mais de 30 anos) no estado médio do clima ou na sua variabilidade, sem identificação absoluta das causas da mudança", advogando o princípio consagrado na UNFCCC de que "estas tanto podem resultar de processos internos naturais ou de forças externas, ou ainda de mudanças antropogénicas persistentes na composição da atmosfera ou no uso da terra" (IPCC, 2001, p. 711) .

No Relatório de Avaliação (AR5) recentemente apresentado pelo IPCC, que coloca as atividades humanas como responsáveis pelo previsível aumento de temperatura na Terra, consta a metodologia do cálculo da média ou da variabilidade das características de um clima durante um longo período de tempo. A base fundamental para este argumento provém dos dados colhidos e registados das amostras do solo, ou seja, dos dados retirados em cada profundidade, que após analisados são associados a uma data na história da terra, e posteriormente comparados ao estado do clima nessa época. Isso permitiu,

\footnotetext{
6 Foi em 1958 que o cientista norte-americano Charles David Keeling fez as primeiras medições da concentração do gás carbônico na atmosfera no vulcão de Mauna Loa, no Havai. O gráfico que mostra a variação da concentração do CO2 na atmosfera desde o início das medições ficou conhecido como a "Curva Keeling". Em memória deste cientista e muito usada no monitoramento deste gás.

7 A Convenção Quadro sobre Alterações Climáticas foi ratificada em Portugal pelo Decreto n. ${ }^{\circ}$ 20/93, publicado no Diário da República n. ${ }^{\circ} 143 / 93$, Série I-A, de 21 de junho de 1993.

8 Texto original: "2. Climate change" means a change of climate which is attributed directly or indirectly to human activity that alters the composition of the global atmosphere and which is in addition to natural climate variability observed over comparable time periods.

9 Texto original: "Climate change refers to a statistically significant variation in either the mean state of the climate or in its variability, persisting for an extended period (typically decades or longer). Climate change may result from natural internal processes or external forcings, or to persistent anthropogenic changes in the composition of the atmosphere or in land use."
} 
com base no padrão criado, constatar que as alterações climáticas sempre existiram, mas não eram tão rápidas como hoje (IPCC, 2013).

A UNFCCC principiou a luta internacional contra as alterações climáticas, abriu o diálogo e incentivou o debate, serviu eficazmente para o reforço da consciencialização mundial, a vários níveis. No entanto, por não contemplar compromissos quantificados e detalhados por país, em termos de redução das emissões de gases de efeito de estufa, dependia de um tratado jurídico internacional, vinculativo quanto à redução de emissões. Este seria o Protocolo de Quioto ${ }^{10}$, cujas negociações começaram durante a primeira conferência das partes (COP1), em Berlim (1995), e foi adotado em 11 de dezembro de 1997, na cidade que lhe emprestou o nome, Quioto (Japão). Entrou em vigor em 16 de fevereiro de 2005. Os Estados que ratificaram o Protocolo de Quioto representam $55 \%$ das emissões de carbono no ano de 1990.

O Protocolo de Quioto, sucedâneo da UNFCCC, herdou desta alguns princípios fundamentais, especialmente o princípio das responsabilidades comuns mas diferenciadas, observável na divisão entre países desenvolvidos (listados no Anexo I - com limites quantificados às suas emissões) e países em desenvolvimentos (conhecidos como os não Anexo I - sem metas quantificadas para a redução de emissões ${ }^{11}$ ). Estabeleceu ainda a aplicação de medidas para limitar as emissões de gases responsáveis pelo aquecimento global nos países desenvolvidos (ou industrializados), e para as reduzir em pelo menos 5\% (em relação aos níveis de 1990), durante o período 2008-2012. O Anexo A do Protocolo lista esses gases: dióxido de carbono $\left(\mathrm{CO}_{2}\right)$, metano $\left(\mathrm{CH}_{4}\right)$, óxido nitroso $\left(\mathrm{N}_{2} \mathrm{O}\right)$, hidrocarbonetos fluorados $(\mathrm{HFC})$, hidrocarbonetos perfluorados $(\mathrm{PFC})$, e hexafluoreto de enxofre $\left(\mathrm{SF}_{6}\right)$, assim como as categorias de emissão setoriais.

Os países listados no Anexo I, nos termos deste Tratado, teriam de reduzir as emissões, mas, caso não conseguissem, ou se considerassem mais vantajoso, poderiam optar por três mecanismos de mercado, com vista à redução das suas emissões de carbono, a saber: Comércio de Emissões (Emissions Trading); Mecanismo de Desenvolvimento Limpo - MDL (Clean Development Mechanism); e Implementação Conjunta - IC (Joint Implementation). Este último, um mecanismo flexível, permitia aos países desenvolvidos do Anexo I reduzir as suas emissões com efeito de estufa sem tomar medidas no próprio país. De entre os países desenvolvidos do Anexo I (da UNFCCC), o Protocolo distingue no Anexo $\mathrm{B}$ um subconjunto de 39 países, com limites quantificados às suas emissões. Existe uma forte semelhança entre os países do Anexo I da UNFCCC e os países do Anexo B do Protocolo de Quioto. A exceção será a Bielorrússia e a Turquia, ausentes neste último.

O tema das alterações climáticas tem ganho relevo e espaço em quase todos os meios, ainda que esta propagação não tenha tido as consequências desejadas, sobretudo mais recentemente, pela introdução de teses de negação das alterações climáticas, por grupos de reflexão conservadores (DUNLAP e JACQUES, 2013) , e pelo recuo das forças políticas mundiais, de que será o maior exemplo os EUA (SOROMENHO -MARQUES, 2012c). Essa negação alimenta-se em grande parte do designado "monstro da incerteza", associado à ciência do clima, que estende a sua teia às incertezas da relação entre ciência e política, e aos desafios que tal representa, à complexidade dos problemas ambientais e do sistema climático, e à

10 O Protocolo de Quioto foi aprovado em Portugal pelo Decreto n. ${ }^{\circ} 7 / 2002$, publicado no Diário da República n. ${ }^{\circ} 71$, Série I-A, de 25 de março de 2002.

11 Para estes países não foram definidas metas quantificadas para a redução das emissões, somente foram definidas medidas (suportadas em recursos financeiros e acesso a tecnologia cedida pelos países industrializados) que, não estancando o seu crescimento económico, permitiam mitigar o crescimento das emissões.

12 Os autores estudaram 108 livros que negam as alterações climáticas, redigidos em língua inglesa, de primeira edição, com ISBN e publicados até 2010 , e concluem que $90 \%$ destes livros não foram submetidos a avaliação de pares, sendo que, na maioria dos casos, os seus autores não têm credenciais académicas e científicas adequadas. Referem que o Instituto Heartland, o Instituto CATO, o Instituto Marshall, entre outros, onde estão muitos dos peritos independentes que servem de "conselheiros" políticos, estão focados em lançar incerteza sobre os estudos das alterações climáticas, minando a credibilidade da ciência do clima e simultaneamente atacando os próprios cientistas do clima. Os autores mostram que os conservadores (CTT) utilizam os livros como forma de espalhar a incerteza sobre as alterações climáticas, rejeitando as evidências de que estamos perante o cada vez maior aquecimento global induzido por ação antrópica e que o aquecimento global vai ter impactos negativos nos sistemas humanos e naturais. A publicação de livros de negação teve um forte crescimento a partir de 2007, um ano depois de Al Gore lançar Uma Verdade Inconveniente (2006), em vídeo e em livro. Este crescimento significativo de publicações ocorre especialmente entre 2007 e 2009, ou seja, o livro de Al Gore, de alguma forma, animou o mercado da negação das alterações climáticas, que se apressou a negar e minar o protagonismo de Al Gore, que recebeu um Óscar para o melhor documentário e o Prémio Nobel da Paz de 2007, em conjunto com o IPCC. 
politização das políticas propostas para reduzir a vulnerabilidade da sociedade às alterações climáticas (CURRY e WEBSTER, 2011).

A negação das alterações climáticas será, porventura, um dos maiores obstáculos ao seu combate. No entanto, as inquietações relativamente à confiabilidade dos modelos, métodos, dados e técnicas científicas, e às incertezas no conhecimento científico gerado, nomeadamente pelo IPCC, que serve de base de informação para decisores/políticos, não se justificam só pela complexidade dos problemas ambientais e do sistema climático, ou pela politização das políticas, ou pelo potencial dos impactos socioeconómicos das alterações climáticas, ou ainda, pela incerteza espalhada por autores sem credenciação académica (DUNLAP e JACQUES, 2013) ${ }^{12}$, devem-se também, salvo melhor opinião, a alguma "redundância lexical", reveladora das limitações enunciadas pelos modelos de estudo do clima, do quanto podem ser perversos os seus resultados e as suas previsões (CURRY e WEBSTER, 2011). A título de exemplo, verifique-se a terminologia na evolução dos relatórios do IPCC.

- No AR4 afirmava-se que "a maior parte do aumento observado nas temperaturas médias globais desde meados do século XX fica a dever-se muito provavelmente (very likely) ao aumento observado nas concentrações antropogénicas de gases com efeito de estufa" (IPCC, 2007 - grifo nosso) ${ }^{13}$.

- No AR5 lê-se que "é extremamente provável (extremely likely) que mais de metade do aumento observado na temperatura média da superfície global de 1951-2010 foi causada pelo aumento nas concentrações antropogénicas de gases com efeito de estufa em conjunto com outras forças antropogénicas" (IPCC, 2013b, p. 17 - grifo nosso) ${ }^{14}$.

Convém referir que, também no AR5, os níveis de confiança relativamente aos efeitos colaterais dos métodos "Carbon Dioxide Removal" [CDR] e "Solar Radiation Management" [SRM] sobre o carbono e outros ciclos biogeoquímicos são muito baixos. Ambos apresentam vantagens e desvantagens, porém o desconhecimento ainda é um facto, referindo uma possível consequência, nomeadamente a intensificação do ciclo hidrológico.

Tudo consubstanciado, o efabular da incerteza pelos "grupos conservadores", como referem Dunlap e Jacques (2013), e o "monstro da incerteza"15 dos modelos climáticos, de que nos falam Curry e WebsteR (2011), fazem com que a ambiguidade permaneça, sobretudo no que se refere à estimativa da contribuição humana para o aquecimento global, como advogam Stott e Hegerl (2014). Morss (2012), no seu artigo publicado na Global Economic Intersection, faz aumentar ainda mais essa dúvida, pois percebemos que não é apenas a China que contribui para o aumento de $\mathrm{CO}_{2}$ na atmosfera $(750 \%$ entre 1971 e 2009); países como o Irão (1119\% no mesmo período) e a Coreia do Sul (890\%, idem) mostram um apetite voraz pelo consumo de energia de origem fóssil, o que remete para a imprecisão das previsões para o futuro próximo contidas nos painéis de avaliação de instituições como o IPCC.

Se temos todos as mesmas responsabilidades perante a ameaça, não somos todos iguais nas respostas que temos de levar a cabo: princípio das responsabilidades comuns mas diferenciadas (SOROMENHO-MARQUES, 2008). Sy (2008) refere mesmo que os países ricos deveriam ser "autoindulgentes", e renunciar aos proveitos do crescimento económico de que desfrutaram nos últimos tempos. Uma perspetiva que é de saudar, por uma questão de equidade na distribuição mundial dos sacrifícios, mas que denuncia um otimismo excessivo que dificilmente consegue uma plataforma de entendimento entre os conservadores e os pró-ambientais, ou entre os defensores da sustentabilidade fraca e os defensores da sustentabilidade forte.

O estilo de vida europeu ou o americano, ainda mais grave, porque assente num consumismo exacerbado e escurado no baixo custo da energia e em orçamentos elevados, que não garante o comércio

\footnotetext{
13 Texto original: "Most of the observed increase in global average temperatures since the mid-20th century is very likely due to the observed increase in anthropogenic concentrations of greenhouse gases" (grifo nosso).

14 Texto original: "It is extremely likely that more than half of the observed increase in global average surface temperature from 1951 to 2010 was caused by the anthropogenic increase in greenhouse gas concentrations and other anthropogenic forcings together" (grifo nosso).

15 O "monstro da incerteza" é um conceito introduzido por Van der Sluijs (2005) numa análise das diferentes formas que a comunidade científica responde às incertezas que são difíceis de domesticar. O "monstro" é a confusão e ambiguidade associadas ao conhecimento versus ignorância, à objetividade versus subjetividade, aos factos versus valores, à previsão versus especulação, e à ciência versus política. Esta incerteza é inerente ao uso de modelos complexos não-lineares.
} 
justo nem o desenvolvimento humano equitativo, contribuem para a insustentabilidade ambiental, pela elevada pegada de carbono, e estão a contribuir intensamente para as alterações climáticas. Na aldeia global todos vão ser afetados, especialmente os países menos desenvolvidos, pela subida do nível da água, pela maior vulnerabilidade social, institucional e falta de infraestruturas (UNDP, 2007; UNDP, 2013); e diga-se, foram os que menos contribuíram para essa situação (SAMSON et al., 2011). Aliás, só agora começaram a contribuir, ainda que de forma intensa, porque as emissões em África passaram de 0,6 para $0,9\left(\mathrm{GtCO}^{2}\right)$, e na Ásia de 6,4 para $9,7\left(\mathrm{GtCO}^{2}\right)$, enquanto a Europa reduziu de 8,2 para $6,8\left(\mathrm{GtCO}^{2}\right)$, dados por comparação entre 1990 e 2003 (BANURI e OPSCHOOR, 2007, p. 7). Isto ocorre porque, tal como a Europa e os EUA centraram a sua economia no consumo de energia, o mesmo estão a fazer estes países, e o aumento de emissões está em linha com a dilatação do consumo de energia, como acontece no Irão e na Correia do Sul (MORSS, 2012). Não obstante o crescimento das emissões nos países em desenvolvimento - algo espectável, como aconteceu durante a industrialização dos EUA ou da Europa -, a sua escala não é comparável à da degradação já provocada pelos países industrializados. O debate aglutinador do modelo de desenvolvimento pretendido, e do custo do combate às alterações climáticas, obriga a um maior esforço de cedência de contrapartidas, pelos europeus, uma vez que na relação população vs poluição, a sua pegada é muito superior (BANURI e OPSCHOOR, 2007, p. 7).

De entre as implicações climáticas da intensificação do efeito de estufa, destacam-se, em termos macro, o aumento da temperatura média do planeta, a alteração do regime de chuvas, a intensificação dos furações ${ }^{16}$, e as tempestades tropicais. Ao nível local e regional as consequências das alterações climáticas de origem antrópica são muitas e diversificadas, como: (i) a desertificação dos campos de cultivo, por via da redução das reservas de água doce e de secas rigorosas, o que pode condicionar a produção agrícola, levando à escassez de alimento, malnutrição e fome (a mudança de clima é ainda favorável à propagação de doenças); (ii) o ataque de pragas em áreas agrícolas e florestais, e tempestades e incêndios mais frequentes, o que leva à diminuição da produção florestal; (iii) alterações nos ecossistemas marinhos, pela aceleração da fusão dos glaciares e aumento da temperatura da água do mar, que provocam inundações e erosão costeira (devido ao aumento do nível da água do mar) ${ }^{17}$, e pelo aumento da acidificação dos oceanos $(\mathrm{pH})$, um verdadeiro desafio à biodiversidade marinha ${ }^{18}$, que poderá levar à degradação dos ecossistemas marinhos (e menor disponibilidade de recursos pesqueiros); (iv) alterações nos ecossistemas terrestres, sobretudo através do avanço dos desertos, pelo desaparecimento de muitas espécies de fauna e flora, e pela transformação de solos férteis em solos áridos, o que leva à redução de biodiversidade ${ }^{19}$ (MAGGS, 1989; DOLAN e WALKER, 2004; BANURI e OPSCHOOR, 2007; IPCC, 2007; WEART, 2008; SAUNDERS e LEA, 2008; ROCKSTRÜM et Al., 2009; GRAHAM e HARROD, 2009; WOLF et al., 2010; SMITHM, 2011; DELICADO et al., 2012; HANSEN et al., 2012; BULKELEY, 2013; SORTE et al., 2013).

A estes fatores que invariavelmente afetam o ser humano ${ }^{20}$, acrescem as previsões que indicam um rápido crescimento populacional nos continentes africano e asiático, o que pode resumir-se num aumento do consumo e consecutivamente multiplica o problema da escassez. Aliás, já se está a verificar com o dilatar do consumo de energia nestes dois continentes, situação que contribuiu amplamente para o aquecimento da temperatura da Terra (BANURI e OPSCHOOR, 2007, p.7).

Concomitantemente, a consequência destes problemas ambientais, sejam eles mais sentidos na dimensão global ou regional, é o aquecimento global, ou melhor, a destruição ambiental

As cidades, suporte espacial da vida humana organizada em sociedade (SANTOS, 2014), responsáveis por $52 \%$ da população mundial, valor que se espera aumentar para $60 \%$ em 2030 (ROLLNICK e NAUDIN, 2011, p. 2), também serão afetadas pelas alterações climáticas. O futuro das cidades é o nosso desafio, não fossem estas a maior criação humana, mas é possível que seja sorridente, como nos

16 Saunders e Lea (2008), para o período entre 1996 e 2005, indicam um crescimento de 40\% na ocorrência de furações devido a uma subida de apenas $0,5^{\circ} \mathrm{C}$ na temperatura da água do mar.

17 Dolan e Walker (2004) referem que as áreas costeiras serão as mais afetas pelos impactos das alterações climáticas.

18 Rockstrüm et al. (2009) aludem à problemática da biodiversidade nos recifes de coral.

19 Hansen et al. (2012, p. 8) alertam que as alterações climáticas trazem consequências negativas ao nível da conversão de terras, destruição de habitats, homogeneização da biota, etc., mas o maior impacto vai ocorrer no ciclo da água.

20 Em referência à humanidade é necessário deixar de utilizar a expressão «Homem», que é uma construção social da masculinidade, que negligencia o género feminino, e começar a adotar a expressão «ser humano». Neste trabalho seguimos esse princípio. 
diz Bulkeley (2013), ao apontar para a necessidade de uma reposta urgente e ambiciosa para responder aos riscos, através da forma como se encaram as opções e escolhas no contexto quotidiano.

São inegáveis os efeitos e consequências que as alterações climáticas induzidas por atividades humanas podem vir a ter na qualidade de vida e no modo de vida das populações.

É sobre estas alterações ao clima, que podem ocorrer a nível regional e global, e que resultam da excessiva emissão de gases do efeito estufa (GEE), que incide este trabalho de base monográfica. Ou melhor, este trabalho visa alertar para a importância da atitude individual (da agência) no combate às alterações climáticas de origem antrópica, classificadas como um dos mais graves problemas ambientais do século XXI. Tal como Haberl et al. (2011), que lembra que os constrangimentos ecológicos podem ser superados pelo trabalho humano e pela criatividade, neste trabalho recorremos à agência como resposta aos problemas ambientais, e das alterações climáticas, indo assim ao encontro do desafio lançado por David Roberts, no seu filme "Climate change is simple": o de fazer algo acontecer, o impossível, ou seja, lutar para travar o aumento da temperatura global (ROBERTS, 2012). Não poderíamos recomendar outra coisa, que todos os indivíduos façam uso da sua agência no combate aos problemas ambientais de natureza antrópica, tema melhor abordado nos capítulos seguintes, mesmo que as estruturas da sociedade não sejam favoráveis a essa pretensão, porque o resultado final pode sempre ser positivo.

\section{A IMPORTÂNCIA DOS PROCESSOS DE SOCIALIZAÇÃO NO COMBATE ÀS ALTERA- ÇÕES CLIMÁTICAS}

A identidade de cada um de nós é influenciada pelo mundo que nos rodeia, ou seja, somos fruto do contexto, da educação e do ambiente de nascimento e criação, tal como se percebe das palavras de Berger et al. (1975), referindo-se à necessidade de adaptação ao mundo, numa experiência que começa com o nascimento:

Bem ou mal, a vida de todos nós tem início com o nascimento (...), e podemos afirmar que a experiência social também começa com o nascimento (...). Desde o início a criança desenvolve uma interação não apenas com o próprio corpo e o ambiente físico, mas também com os outros seres humanos. A biografia do indivíduo, desde o nascimento, é a história das suas relações com as outras pessoas. (BERGER et al., 1975, p. 200). (a citação deve ser compreendida no contexto que a precede).

É neste contexto que vai acontecer a socialização, de forma natural, já que decorre de um processo contínuo, que se inicia com a formação do feto através dos estímulos que este recebe da progenitora e que criam uma relação de aprendizagem, que vai permitir à criança absorver informação importante para o seu desenvolvimento, tanto cerebral como de perceção.

Não obstante, como refere Anthony Giddens (2004, p. 29), "tal não significa que seja negada individualidade ou livre arbítrio aos seres humanos", ou seja, a nossa interação com o ambiente que nos rodeia e com as estruturas da sociedade molda a nossa personalidade e o nosso comportamento, por força de normas morais e hierárquicas e princípios consuetudinários, mas cabe a cada um de nós, individualmente, desenvolver um sentido crítico que nos identifique em relação aos restantes, com capacidade de pensar e agir de forma independente. O ditado já é velho, mas parece correto e adequado: "eu não escolhi o que sou (condicionado pela estrutura) mas posso escolher o que quero ser

\footnotetext{
21 "Mais aussitôt après je pris garde que, pendant que je voulois ainsi penser que tout étoit faux, il falloit nécessairement que moi qui le pensois fusse quelque chose; et remarquant que cette vérité, je pense, donc je suis, étoit si ferme et si assurée, que toutes les plus extravagantes suppositions des sceptiques n'étoient pas capables de l'ébranler, je jugeai que je pouvois la recevoir sans scrupule pour le premier principe de la philosophie que je cherchois" (DESCARTES, 1637, p. 36 - grifo nosso). (Mas, logo em seguida, notei que, enquanto assim queria pensar que tudo era falso, eu, que assim o pensava, necessariamente era alguma coisa. E notando esta verdade: eu penso, logo existo, era tão firme e tão certa que todas as extravagantes suposições dos céticos seriam impotentes para a abalar, julguei que a podia aceitar, sem escrúpulo, para primeiro princípio da filosofia que procurava - tradução nossa). Foi uma das primeiras obras filosóficas modernas não escrita em Latim. O autor pretendia que mais pessoas lessem o seu trabalho e pensassem por si mesmas, incluindo as mulheres. Acreditava que as pessoas ao lerem a sua obra distinguiriam o verdadeiro do falso pela luz natural da razão. Procurou dotar as pessoas de sentido crítico e conhecimento, de confiança e determinação, caminho percursor da agência.
} 
(pela agência)".

A agência (agency) é um conceito antigo, nascido (senão antes) da célebre frase "cogito ergo sum" (penso, logo existo), de René Descartes, inicialmente inscrita na Parte 4 da obra Discours de la méthode ${ }^{21}$ (1637) e, posteriormente, na Parte 7 da obra Principia Philosophiae (1644). Nesta altura considerava-se que qualquer cidadão que conseguisse pensar era um agente, e qualquer agente era capaz de pensar e refletir sobre um determinado assunto; definição continuada desde o ilusionismo até ao século XIX, altura em que é descontinuada, e se aceita que as escolhas humanas não dependem só da vontade própria, da razão, mas podem ser determinadas por forças externas.

Não obstante as várias interpretações atuais, neste trabalho vamos considerar a agência como a capacidade do ser humano para agir de forma independente e de fazer as suas próprias escolhas livres (STONES, 2007; BARKER, 2008; GULATI \& SRIVASTAVA, 2014; EICHNER, 2014). Ou seja, a capacidade de, individualmente ou em grupo, influenciar os acontecimentos, mitigando os efeitos das alterações climáticas (Wilson et al., 2012, p. 155).

Para que exista agência, é necessário existir vontade própria e autonomia de decisão, e uma perceção ou consciência cívica que contrarie o "statu quo" dominante.

Das três abordagens sobre o conceito desenvolvimento sustentável, "statu quo", "reformistas" e "transformadoras", classificadas e mapeadas por Hopwood et al. (2005), é a transformadora, comprometida com a equidade social e com a qualidade ambiental, a que está mais próxima do conceito de agência agora proposto. Apresenta preocupações com os problemas ambientais e sociais que estão presentes na sociedade, resultado da forma como o ser humano se relaciona com os seus pares, e do modo como interage com o ambiente, e procura a efetiva transformação para uma sociedade mais sustentável.

A estrutura é representativa dos fatores que influenciam as oportunidades e condicionam a agência dos indivíduos (ex. fatores como educação, religião, sexo, família, classe social, subcultura, etnia, entre outros) (STONES, 2007). No entanto, sabemos que a estrutura é produzida e reproduzida pelas ações dos indivíduos, não tem de ser inflexível, pelo contrário, depende dos indivíduos a sua reformulação com vista à mitigação das alterações climáticas de origem antrópica (GIDDENS \& PIERSON, 1998, p. 77): "Society only has form, and that form only has effects on people, in so far as structure is produced and reproduced in what people do".

A aplicação do conceito de agência, no âmbito da compreensão das questões das alterações climáticas, excede o universo das sociedades organizadas, , e pode e deve ser estendida às sociedades sem Estado (CLASTRES, 1979), muitas vezes erradamente consideradas arcaicas e sem poder, devido ao etnocentrismo cultural do pensamento ocidental. Nestas sociedades a agência geralmente é visível em contextos de reconfiguração social, quando existe alteração da estrutura de vivência. Mas nem sempre é considerada, mesmo pelos especialistas, por ser a parte menos visível.

Roberto Cardoso de Oliveira e Darcy Ribeiro, quando procuraram responder às primeiras questões sobre o contacto no Brasil, enfatizaram o conceito de fricção-étnica, visível na economia, no trabalho, na organização social, no sistema clânico e de parentesco, que consideraram responsável pela gradual caboclização. Do ponto de vista económico, referem que o trabalho e a produção doméstica passaram a inserir-se na economia mercantil, e que as tarefas do trabalho foram direcionadas para o extrativismo (recursos naturais e minerais), frente agrícola e frente pastoril (ex. extraem latex, utilizado na borracha, somente para vender ao branco). Com base nesta visão dos povos indígenas brasileiros, de submissão e/ou vassalagem, apontam para o fim da genuinidade indígena, porque consideravam que os Índios estavam a passar por um processo de transfiguração étnica: de índios específicos para índios genéricos (OLIVEIRA, 1994; RIBEIRO, 1996). Argumentação que retira protagonismo à agência da população indígena e, do ponto de vista ambiental, pela extração de recursos, remete para a insustentabilidade.

No entanto, outras tendências eram possíveis, como vieram a acontecer, que não negando o impacto negativo do contacto na cultura indígena, e as consequências do extrativismo mercantil, invocam outros planos de análise menos negativistas, como a cosmologia, o ritual ou a mitologia; é exemplo disso Catherine Howard, que logo a seguir apresenta uma visão que restitui a agência ao índio, considerando que estes são ativos nos processos de reconfiguração social e também no contacto, ou seja, são agentes deles próprios (HOWARD, 2000).

Os conceitos de "territorialização" e "viagem da volta", de que nos fala João Pacheco de Oliveira, no âmbito dos movimentos de identidade indígena (o conjunto de processos de reafirmação e revitalização da identidade indígena no Brasil), e que explicam o processo de renascimento étnico do 
Nordeste (NE) brasileiro, são também fontes importantes de agência. A territorialização nos grupos indígenas do Nordeste, conceito pensado à luz das contribuições de Fredrik Barth, remete para uma viagem de volta dos índios para recuperar o que perderam ao longo do tempo e criar uma nova unidade sociocultural mediante o estabelecimento de uma identidade étnica diferenciadora, com mecanismos políticos especializados e controle social dos recursos ambientais, e a revitalização da cultura e da relação com o passado (OLIVEIRA, 2004). Demonstra que é possível fazer a diferença a partir da vontade individual e da disponibilidade coletiva, ou seja, que nós (humanos) podemos determinar a estrutura de vida e definir métodos de ação e vivência, combinando ambos os conceitos, que não têm de ser opostos, como nos referem Howard (2000), ou Allen e Thomas (2000) apud Wilson et al. (2012, p. 155).

Giddens (2004, p. 9) indica algumas das principais fontes de identidade: o género, a orientação sexual, a classe social, a nacionalidade e a etnicidade, e distingue identidade social de identidade pessoal. Refere que é na identidade pessoal que nos distinguimos enquanto indivíduos, produto ou resultado de um processo de aprendizagem pessoal através do qual "formulamos uma noção intrínseca de nós próprios e do relacionamento com o mundo à nossa volta". As decisões que tomamos, desde as mais simples até às mais complexas, tornam-nos o que somos, como advoga Giddens (2004, p. 30): "o mundo moderno força-nos a tornar-nos quem somos (...) como seres humanos cientes e auto-conscientes, criamos e recriamos as nossas identidades a todo o momento".

Esta afirmação de Anthony Giddens é rica pela informação e mensagem, pois refere que somos nós que temos de comandar o nosso navio, e para isso temos que, de forma consciente, criar e recriar a nossa identidade no contexto onde nos inserimos, nunca esquecendo que a socialização também representa liberdade, intimidade e individualidade.

Introduzindo a questão de outra forma, tal como a protagonizou Benedict Anderson, ao trabalhar a nação como uma comunidade imaginada, ao mesmo tempo limitada e soberana, e dando especial atenção à questão da nação imaginada, onde os seus membros não se conhecem, embora todos eles a idealizem e tenham uma imagem da comunidade, são os cidadãos que criam os limites da nação, e o mundo onde vivem (ANDERSON, 1991), produzindo e reproduzindo a estrutura pelas suas ações (GIDDENS \& PIERSON, 1998).

Esta conceção tem paralelo com as questões das alterações climáticas. Se a nação pode ser imaginada, construída como uma profunda relação horizontal da sociedade (apesar das divergências internas), formando alianças imaginárias na nação e entre nações que chegam a conduzir homens a grandes sacrifícios e a mortes heroicas, também pode conduzir os homens ao progresso harmonioso e ao desenvolvimento sustentado, estabilizando a emissão dos gases com efeito de estufa, estudando e controlando o aquecimento do planeta de origem antrópica, bastando para isso fazer o indicado por Giddens (2004), ou seja, sermos nós próprios a tomar decisões de forma consciente.

Wilson et al. (2012, p. 155-171) reportam primeiramente para as estruturas sociais de vivência, por extensão da ação/agência individual e sentimento de poder na sociedade de referência, o que a nosso ver representa elementos de uma socialização secundária, do decurso da vida. Numa abordagem mais completa e complexa temos de pensar nos processos de socialização em duas fases: socialização primária, desde o nascimento até à adolescência, levada a cabo essencialmente pela família e pela escola, e socialização secundária, que ocorre durante a vida adulta, da responsabilidade das estruturas sociais e relações de poder estabelecidas, dos grupos nos quais os indivíduos se inserem, sobretudo do laboral e/ou académico, que determinam em parte a capacidade de agência. É por intermédio do processo de socialização que os indivíduos aprendem os seus papéis sociais - expectativas socialmente definidas seguidas pelas pessoas de uma determinada posição social (GIDDENS, 2004).

Os agentes de socialização, enquanto "grupos estruturados ou contexto em que ocorrem os processos de socialização significativos", são os promotores do processo de socialização (GIDDENS, 2004). Segundo o autor, a família é o principal agente de socialização da criança durante a infância, em todas as culturas, ainda que também existam outras influências, onde se incluem os "grupos de pares, escolas e meios de comunicação". Estes agentes de socialização são fundamentais para a promoção das questões ambientais, sobretudo a família, por ser essencial nos primeiros anos de vida da criança, quando ocorre a interação inicial com o mundo que a rodeia.

É através da família que a criança inicia a aprendizagem básica e as relações afetivas. A família pode mesmo ser considerada um elo fundamental para a mudança do paradigma ambiental, quando formada por elementos que promovam práticas ambientais construtivas, porque é muito provável 
que a criança na sua vida adulta reproduza hábitos e adote uma vivência de acordo com as normas interiorizadas. Esta questão alerta-nos para a importância da família na promoção de uma sociedade mais justa e ambientalmente responsável. Não obstante, em todas as culturas essa aprendizagem recebe influências de outros agentes de socialização, que podem proceder à integração dos indivíduos ou à sua ressocialização.

Os grupos de pares também têm um papel ativo no processo de socialização do indivíduo. O ser humano, que possui uma forte natureza gregária, tem necessidade de se integrar em grupos, acabando por ser modelado e por modelar as expectativas e vivências de outros indivíduos com os quais apresenta afinidades. Em relação à problemática ambiental, e no que às alterações climáticas diz respeito, os grupos de pares poderão influenciar a forma como cada indivíduo perceciona e vive os problemas decorrentes das atividades humanas sobre o meio, portanto, a sua agencialidade. Quando um determinado grupo tem uma intervenção mais ativa, e participa em discussões e organiza atividades de promoção de redução das emissões de gases de efeito de estufa, por exemplo, pode levar o indivíduo (membro) a assumir posições que individualmente não tomaria, potenciando o desenvolvimento sustentável. Pode também acontecer o inverso, isto é, um grupo pode defender um modo de vida agressivo para o ambiente ou simplesmente ignorar a problemática ambiental. Neste caso o indivíduo acaba por se afastar dos meios de defesa e não promove uma atitude ambiental de ação positiva.

A escola é um agente fundamental na problemática das questões ambientais, porque, para "além de contribuir ela própria para mudanças sociais e culturais de fundo, (...) recebe os impactes dos processos globais de transformação societal" (ALMEIDA, 1994, p. 118). Tem um papel fundamental na promoção dos direitos e deveres dos alunos, e é essencial na dinamização da educação ambiental e da educação para o desenvolvimento sustentável. A instrução dos alunos levada a cabo pela escola, realizada com base nos currículos (nesse âmbito, para se tornar mais ativa e decisiva na interiorização, requer uma mudança na forma como encaramos a sua função), transmite ao aluno um conjunto de conhecimentos que ele tem de interiorizar e reproduzir, promovendo, por vezes, uma atitude de desafio e discussão sobre a informação instituída. Como advoga Carapeto (1998), "podemos encarar o ensino como um processo organizador de transmissão de conhecimentos ou de organização de aprendizagens, que visa, por isso, a formação intelectual dos alunos. São instruções e explicações dadas para um uso especial. O processo de educação visa, de outra maneira, a formação geral e integral, que acrescenta à formação intelectual, a formação sócio-afetiva e moral".

A família e a escola, apesar da sua inegável importância, estão a perder peso no processo de socialização da criança e do jovem, surgindo outros agentes que ocupam um lugar de primazia, a denominada escola paralela. Os jovens começam muito cedo a ter contacto com o mundo através dos meios de comunicação social, que se tornam essenciais à sua socialização, aculturação e formação. A televisão começou por ser o meio de comunicação social com maior capacidade de captação e retenção de atenção, fruto do seu capital simbólico (na aceção de BOURDIEU, 2003). No entanto, na transição do milénio, com a massificação da internet, surgiram mais intensamente outros agentes que podemos considerar fundamentais no processo de socialização dos indivíduos.

Embora os efeitos da internet e dos computadores ainda não tenham sido profundamente estudados, não podemos ignorar ou minimizar a importância que estes têm para as gerações atuais. Através de um conjunto de instrumentos como os blogues, chats, redes socais, entre outros, a internet assume cada vez mais um papel fundamental no processo de socialização das gerações mais novas. A internet tem a capacidade de atrair diariamente milhões de crianças e jovens que ocupam grande parte do seu tempo livre a navegar nas suas páginas, a alimentar as redes sociais. O Facebook, criado em 2004, foi muito importante na dinamização das redes sociais. Em 2007 já tinha mais de 21 milhões de membros registados (nessa altura um utilizador típico gastava cerca de 20 minutos por dia no site) (ELLISON et al., 2007, p. 1144). Já se verificam muitos movimentos de promoção ambiental que

22 Segundo Ellison et al. (2007), os inquiridos em idade universitária, que utilizam o Facebook, estão mais envolvidos nas medidas do capital social (ELLISON et al., 2007). Portanto, as interações online que os sites de redes sociais proporcionam não têm de ser vistas como "nocivas", quando mantêm em contacto pessoas que estão em constante mudança pelo mundo. Além de ajudar os estudantes, por exemplo, a obterem mais benefícios com a sua experiência universitária, podem contribuir ainda para auxiliar um indeterminado número de pessoas que precisam de manter laços, e são estruturantes para a sustentabilidade. O Facebook pode ainda servir para diminuir as barreiras à participação por parte de pessoas que se retraíam/coibiam de iniciar a comunicação com ou responder a outros. São, portanto, encorajadas a fazê-lo através das affordances do Facebook (HALPERN et al., 2013). O uso desta rede social pode estar a contribuir para a superação das barreiras com que se deparam as pessoas que têm baixa autoestima e baixos níveis de satisfação. 
surgem e são divulgados nos espaços virtuais. Os agentes de socialização não podem ser encarados individualmente, todos contribuem para a interiorização de normas e valores. No entanto alguns têm um peso superior a outros, como é o caso das redes sociais na atualidade.

Os sites de redes sociais, como o Myspace, Linkedin, Friendster, Cyworld e, claro, o Facebook, não só permitem manter relações online com pessoas desconhecidas, como permitem estabelecer novos laços (ELLISON et al., 2007, p. 1143-1144). São determinantes na socialização primária e secundária, quando existe conteúdo formativo para o desenvolvimento sustentável, e, consequentemente, para a mitigação da poluição atmosférica. As redes sociais fornecem uma conexão fácil, primeiramente com outros indivíduos que tenham interesses idênticos, fortalecem a comunicação entre a população universitária, e proporcionam uma fácil ligação ao mundo do trabalho. Estas sustentam a manutenção e criação de laços sociais e de novas conexões ${ }^{22}$. Os laços sociais surgem da ideia de interação social. Quanto maior o número de laços sociais mais os indivíduos se encontram conectados entre si numa rede. É importante evidenciar que os vínculos baseados na internet criam a formação de laços fracos ${ }^{23}$ que servem de base para a evolução do capital social (RECUERO, 2005, p. 16). As redes sociais instituem-se como um instrumento determinante na luta em prol de um mundo mais sustentável, uma vez que grande parte de movimentos de contestação e protesto, de cariz ambiental e outros, têm ponto de partida nas redes sociais, nomeadamente o Facebook.

Durante a socialização primária - processo de aprendizagem que começa ainda com o feto na barriga da progenitora, momento em que a capacidade de descodificação da informação que recebe e absorve ainda não lhe permite questionar e constituir uma identidade - a criança reproduz o que recebe do exterior. É aqui que os progenitores devem intervir e fomentar o interesse das crianças por questões ecológicas, período em que estão mais recetivas.

Mesmo ainda na barriga da mãe o feto já pode perceber e identificar sinais sonoros, como reconhecer a voz da mãe, sonhar, descodificar e memorizar a forma como a mãe engole os alimentos; começa a adquirir conhecimento. Normalmente, no pós-parto, é a voz da progenitora que o recémnascido mais conhece, e que mais gosta de ouvir, daí ser normal chorar quando a mãe se afasta. Isto demonstra que durante o período de gestação existe uma comunicação ativa, consciente e inconsciente, entre mãe e filho, que se vai intensificar logo após o nascimento através do desenvolvimento biopsicoafetivo da criança (ROSA et al., 2010, p. 106), cimentando-se de tal forma que cria um elo que normalmente só se rompe com a morte. É esta, portanto, a fase de aquisição da capacidade de comunicação simbólica, da interpretação do mundo que o rodeia, da aquisição de valores, estruturas, referenciais e caracteres, e da aquisição de informação rotineira que resulta da sua observação sobre as atitudes e atividades dos seus progenitores. Constitui a primeira fase da vida, processo pelo qual as "crianças aprendem atitudes, valores, normas e comportamentos transmitidos pelos pais, representantes da sociedade em geral" (AMARO, 2006).

É aqui, no pós-parto, que deve começar a formação para a educação para o desenvolvimento sustentável, como advoga Amaro (2006): "é nesta fase que se inicia a formação do self e que se desenvolve a capacidade que nos permite colocar no lugar dos outros, a fim de compreendermos as suas expectativas a nosso respeito e podermos corresponder com um comportamento adequado." Os progenitores devem ensinar pelo exemplo, explicando às crianças o motivo da ação, para que o possam assimilar, e assim formular um pensamento consistente e não de fazer por fazer.

Aqui reside a chave da identidade da criança enquanto pessoa, os alicerces que determinam a sua agência e a sua relação com as estruturas da sociedade na vida adulta, tal como o interpreta Rudolf Steiner, fundador da pedagogia Waldorf, que conjetura que toda a verdadeira compreensão supõe a capacidade de percecionar. Uma experiência sensorial na sua máxima amplitude tem um papel fundamental no desenvolvimento dos sentidos, processo que acontece ao longo dos primeiros anos de vida da criança.

O passo seguinte no processo de aprendizagem é o progressivo aumento da tomada de consciência daquilo que compreende. A criança aprende então a reconhecer os aspetos essenciais de um determinado fenómeno. A aproximação fenomenológica às ciências naturais e humanísticas, cujo início se produz na quarta classe, tem um papel central na educação de Waldorf. Pela sua importância a pedagogia de Rudolf Steiner já existe em cerca de 994 escolas independentes, 1600 jardim-de-infância,

23 Como refere Recuero (2005, p. 16), "são os laços fracos os mais beneficiados pelo uso da rede social". 
centenas de estabelecimentos de pedagogia e 60 institutos para a formação de professores em mais de 50 países (até 2010).

No início do século XX, Rudolf Steiner afirmava que no começo do século XXI as crianças seriam confrontadas com problemas sociais e ecológicos a nível planetário, e que teria de existir uma alteração de paradigma. Ficou célebre pela frase: "a nossa mais elevada tarefa deve ser a de formar seres humanos livres que sejam capazes de, por si mesmos, encontrar propósito e direção para suas vidas". Steiner não se enganou nas suas previsões, e muitas das preocupações ambientais atuais, como o aquecimento global, podem ser ultrapassadas pela adoção de uma socialização primária rica em educação ambiental, onde a criança importa, interioriza e introduz significado ao que passa em seu redor.

Quando as crianças chegam à designada socialização secundária, reportando para o decurso da vida, onde é exigida uma vigorosa agência e bastante responsabilidade, estas estruturas e caracteres iniciais já têm de estar cimentados e articulados, e a criança já deve ter uma identidade própria.

Se a criança respeitar o ambiente natural, e se essa informação estiver na sua matriz identitária, vai adotar práticas conscientes para mitigar o aumento do aquecimento global, e pode intervir e influenciar positivamente as pessoas em seu redor, o grupo onde está inserida, e a descendência, se for o caso. Isto é por em prática a sua identidade, que pode reformular quando for necessário, tanto para o bem como para o mal. Por exemplo, um indivíduo que recebeu uma boa educação para o desenvolvimento social e a sustentabilidade pode, na fase adulta, perder essa identidade por influência de um determinado grupo social onde se venha a inserir. Mas o contrário também é possível, ou seja, é possível um cidadão receber e absorver caracteres amigos da sustentabilidade num estádio de vida superior sem que tenha recebido na infância uma educação respeitadora dos valores sociais e da sustentabilidade. Para esse realinhamento identitário, pró-ambiental, o indivíduo necessita saber conviver com fatores como relacionamento interpessoal, intrapessoal e organizacional, e lidar com atitudes ou motivações adversas. A reeducação, quer seja no seio de um grupo já com essa consciência, quer seja no seio de um grupo sem essa consciência, é possível e demonstra uma postura de responsabilidade.

$\mathrm{Na}$ idade adulta os grupos ligados ao mundo laboral são importantes agentes de socialização secundária, quando " (...) as estruturas sociais, os sistemas normas e valores, as correntes ideológicas, e as configurações de sentido estejam em relação, a vários níveis através de mediações diversas, com o mundo do trabalho das profissões" (ALMEIDA, 1994, p.75). É um meio que permite aos membros do grupo influenciar, mas também serem influenciados. O trabalho permite o acesso a recursos materiais e a um conjunto de princípios subjacentes às questões profissionais. $\mathrm{O}$ indivíduo integra no seu projeto pessoal de vida o profissional, cujas normas e valores poderão influenciar a forma como encara as diversas temáticas. Por vezes adquire um nível de vida diferente do que tinha durante a socialização primária. Se o grupo de trabalho onde está inserido estiver informado e mostrar abertura às problemáticas ambientais, o indivíduo tornar-se-á mais ativo; se, pelo contrário, for um local de manifesta passividade ou de incompreensão da sustentabilidade, o indivíduo pode ter uma atitude passiva ou até negligente. No entanto, pode acontecer o inverso, situação que todos desejaríamos, isto é, pode o grupo não mostrar abertura para as questões ambientais e o indivíduo com grande agência influenciá-lo no sentido dessa abertura, podendo realizar essa tarefa com grande propriedade e com resultados efetivos do seu trabalho.

Estas duas fases do processo de socialização secundário definem a identidade de cada indivíduo, "uma imagem de si próprio que é essencial à sua vida e lhe permite seleccionar as acções e as relações sociais", criando um "quadro de referência para valorização de si próprio e autojustificação, estruturando a acção individual" (AMARO, 2006).

Concluímos que os agentes de socialização são fundamentais para a interiorização de valores e normas ambientais no combate às alterações climáticas e, neste contexto, torna-se fundamental a promoção de uma educação para o desenvolvimento sustentável por parte da família, escola, grupo de pares, comunicação social e, com um papel cada mais decisivo, pela internet e recursos que lhe estão associados. Podemos ainda arrolar ao tema o papel de outros grupos de pertença mais alargados, como as associações cívicas e/ou defensoras do ambiente (ex. ONG). Neste caso, mesmo os indivíduos que não pertençam a tais grupos e/ou não adiram às suas propostas de desenvolvimento social e ambiental acabam por interiorizar preocupações, ganhar crenças e valores, possibilitando a modificação de práticas quotidianas.

A atitude individual (agência), a postura perante as estruturas sociais, o cumprimento de normas, regras e deveres, determinante para formular capital social (PORTES, 2000; PUTNAM, 2002), 
até mesmo o poder que o indivíduo sente no interior do conjunto das estruturas sociais e formações grupais em que se movimenta, e que lhe são próprias (WILSON et al., 2012, p. 155), são o resultado do quadro de valores absorvidos no contexto familiar e no meio envolvente: local (em grupo laboral, social, familiar, desportivo, ambiental, cultural, musical, entre outros) e global (estruturas sociais regionais, nacionais, europeias e mundiais).

É no processo de socialização primária que se deve iniciar a consciencialização socio-ambiental no combate às alterações climáticas, para que na fase adulta os indivíduos se transformem em abelhas e procedam à polarização de boas práticas, que tanta falta faz em Portugal, na Europa e no Mundo, com destaque para os Estados Unidos da América, que foi no passado recente o principal emissor de gases com efeito de estufa (35\% das emissões totais em 1990), mas que não ratificou o Protocolo de Quioto, justificando a sua decisão com o facto de a China não estar no acordo (SUNSTEIN, 2007). Esta situação tem contribuído para o atraso nas negociações, porque a ausência dos EUA no Protocolo é invocada por outros países para também ficarem de fora ${ }^{24}$. Isso verificou-se na Conferência de Doha (2012) (COP18), em que saíram do acordo o Canadá, o Japão, a Nova Zelândia e a Rússia, o que dificultou as negociações, ainda que, não obstante o embaraço, no final se conseguisse um acordo mínimo, para estender o Protocolo de Quioto até 2020.

No entanto, não basta que só os cidadãos cumpram os seus deveres socio-ambientais, porque a sustentabilidade engloba a questão social, ambiental, económica e de governança. Não se trata da governança da dimensão económica, social ou ambiental, mas da governança num sentido mais amplo, agregando ao conceito de Desenvolvimento Sustentável a "capacidade das pessoas e das organizações da sociedade, mediante o uso de instrumentos e sistemas da democracia, definir o rumo do seu desenvolvimento e, portanto ter condições de exercer controlo sobre políticas públicas e sobre a dinâmica económica" (BORN, 2011, p. 4).

Esta governança, numa aproximação ao institucional referido por Soromenho-Marques (2012a,b), implica que, no processo de socialização secundário, ao nível da interação dos agentes políticos e organizações internacionais, terá que existir uma efetiva atitude de combate às alterações climáticas, suportada com políticas adequadas e equitativas no espetro planetário.

Como referem Hopwood et al. (2005), a abordagem reformista considera que existem atualmente vários problemas e critica as políticas adotadas pelas empresas e pelos governos, mas, no entanto, não é desejável a rutura atual nos sistemas, social e ecológico, e o desenvolvimento tecnológico, e os governos, entre outros, segundo esta abordagem, são fulcrais, no progresso, em direção ao desenvolvimento sustentável. Ou seja, não podem ser pensados como elementos prescindíveis, mas como stakeholders que precisam de ser consciencializados.

Depois do fracasso da Conferência de Copenhaga (2009) (COP15), que não atingiu os planos de discussão ambicionados, e do fracasso da Conferência de Durban (2011) (COP17), na definição do sucessor de Quioto, que levou, em recurso, na Conferência de Doha (2012) (COP18), ao prolongamento da vida do Protocolo de Quioto até 2020 (expiraria em 2012), espera-se que os países, ou os grupos de países (blocos), prescindam da usual avaliação de curto prazo de problemas que colocam em causa o desenvolvimento sustentado e o futuro das gerações, e que os agentes políticos nacionais evitem o caminho para as alterações climáticas catastróficas, de origem antrópica, com base em decisões relevantes e grande agência na negociação em curso, que pretende levar a comunidade internacional a adotar, o mais tardar em 2015, na Conferência das Partes em Paris (2015) (COP21), um novo acordo universal juridicamente vinculativo, a partir de 2020, em substituição de Quioto (alargado aos países em vias de desenvolvimento ${ }^{25}$. Concretamente, espera-se o sucesso da Plataforma de Durban, e do plano de negociações entre EUA, China e Índia, até porque, a China é líder desde 2006 na emissão de gases poluentes (WILSON et al., 2012; MARCATTO, 2013). Não podemos negligenciar a indicação de que nos últimos 100 anos a temperatura média do ar na superfície terrestre aumentou de 0,3 para $0,6^{\circ} \mathrm{C}$,

24 As dificuldades em negociar algo tão complexo, as emissões de gases com efeito de estufa, resultam dos principais emissores, EUA e a China, não terem interesse em reduzir as emissões de forma unilateral. Como refere Sunstein (2007, p. 3), "the reason is that such unilateral reductions would impose significant domestic costs and, by themselves, would be unlikely to produce significant domestic benefits. By contrast, the principal victims of climate change, above all in Africa and India, are not the principal contributors; their own efforts at emissions reduction will do nothing (in the context of Africa) and close to nothing (in the context of India) about the problema".

25 Convém referir que nenhum destes países está obrigado a metas de corte nas emissões até 2020. Os EUA porque não são signatários do Protocolo de Quioto, e a China e Índia porque esse não estipula metas para os países em desenvolvimento. 
que a atuação humana continua a contribuir significativamente para o aumento da temperatura, que o balanço das evidências continua a demonstrar porque é pouco provável que o aquecimento verificado resulte de causas naturais, e que, no futuro, nas melhores previsões, a temperatura terrestre oscilará entre $0,3^{\circ} \mathrm{C}$ e $1,7^{\circ} \mathrm{C}$, e a variação do nível do mar entre 26 e 54 centímetros, ao longo do século até 2100, como consta do quinto Relatório de Avaliação (AR5) do Intergovernmental Panel on Climate Change (IPCC) (a concluir no final de 2014) (IPCC, 2013, p. TS-75). Nas piores previsões, a temperatura oscilará entre $2,6^{\circ} \mathrm{C}$ e $4,8^{\circ} \mathrm{C}$, e a variação do nível do mar entre 45 e 81 centímetros (IPCC, 2013, p. TS-75-TS-78). Precisamos da tecnologia, e da nossa boa vontade, para combater este aumento brutal da temperatura. Sem a nossa agência ao serviço do Planeta, tudo fica como está, e não está nada bem, como se pode ver pelo aumento da temperatura nos últimos 100 anos.

Em jeito de retrospetiva, neste capítulo abordámos a formação da identidade dos indivíduos, passando pela socialização primária e secundária, e refletimos sobre a forma como essa identidade pode e deve ser formatada e direcionada para a cidadania e participação ambiental, mesmo em situação de reeducação e reaprendizagem. Também demonstrámos que a agência é muito importante para combater as alterações climáticas, porque, por via da ação individual, nas práticas quotidianas, é possível mitigar o aumento da concentração de gases com efeito de estufa (GEE) na atmosfera, e consequentemente contribuir para a redução da temperatura média global.

A seguir apresentamos um caso de estudo, uma reflexão sobre a história de vida do autor, explicativa de quanto a sua interação com a estrutura da sociedade moldou a sua ação individual e influenciou a sua atitude perante os desafios da sustentabilidade, nomeadamente das alterações climáticas. É um testemunho da importância da agência e um apelo à adoção de práticas de vivência consentâneas com a capacidade de carga do Planeta.

Localização geográfica do local de nascimento/socialização primária ${ }^{27}$

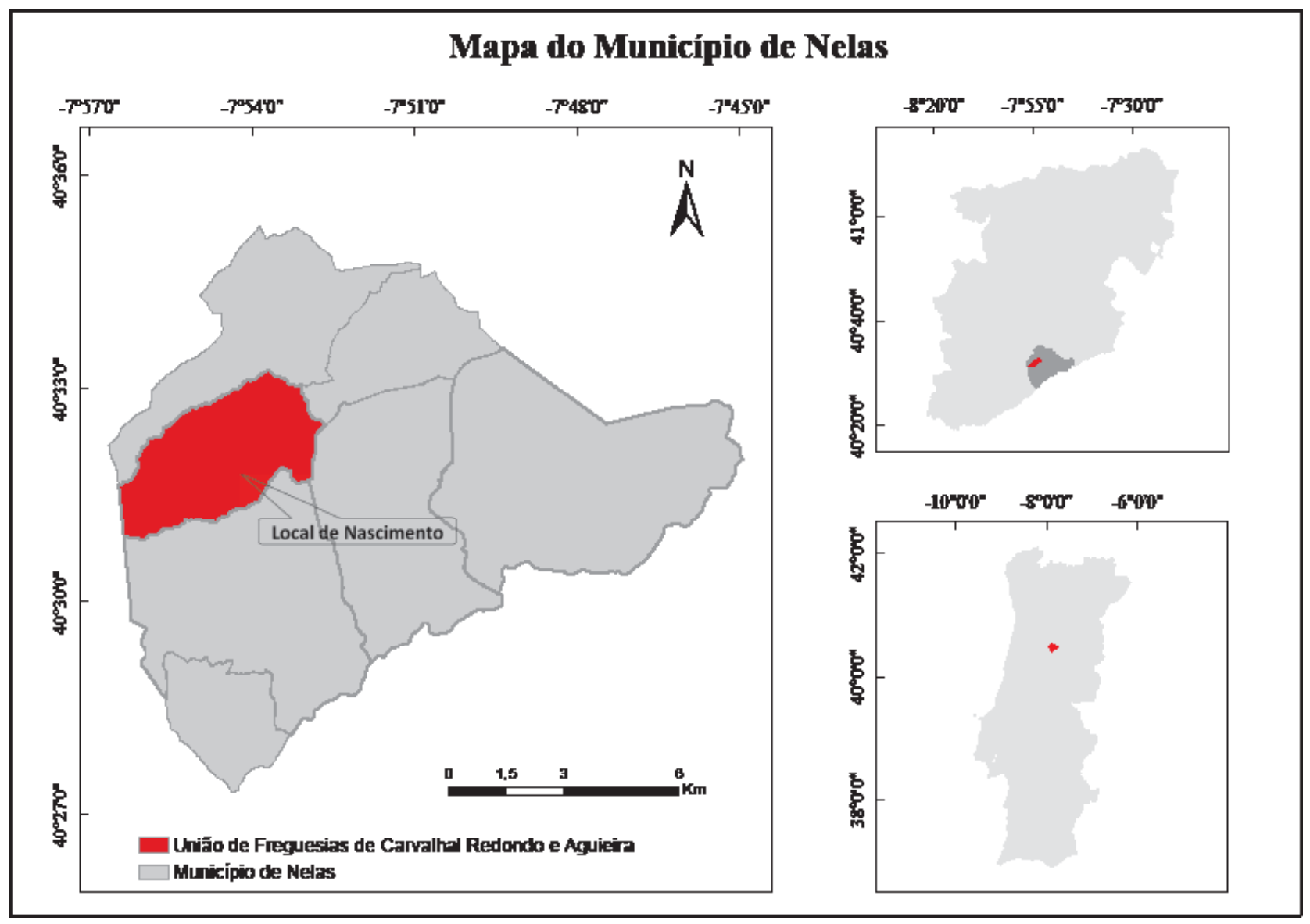

26 Latitude de (4031' 52"' N) e Longitude de (7 54' 29'” W).

27 Sistema de Coordenadas Geográficas: Datum 73, sistema de Hayford-Gauss. Instituto Português de Cartografia e Cadastro (IPCC). Elaboração própria. 


\section{A IMPORTÂNCIA DA AÇÃO INDIVIDUAL NO COMBATE ÀS ALTERAÇÕES CLIMÁ- TICAS.}

\subsection{Caso de estudo - a vida do autor}

No seguimento da abordagem teórica anterior, posso dizer que toda a socialização primária foi realizada sem qualquer referencial de sustentabilidade, pelo isolamento do local de nascimento (espaço rural) (Carvalhal Redondo/Nelas/Viseu/Portugal) ${ }^{26}$, baixas habilitações escolares dos progenitores $\left(4^{a}\right.$ classe incompleta), dificuldades económicas (agricultura de subsistência), e data de nascimento (1982), altura em que existia uma mentalidade individual e coletiva pouco evoluída em termos de desenvolvimento sustentado; algo que afetava não só o interior, mas todo o Portugal. Isto não é uma crítica aos agentes de socialização atrás referidos - família, escola, grupos de pares e comunicação social - uma vez que esses não estavam habilitados para fomentar valores e normas ambientais.

O conceito de Educação Ambiental começou a ser introduzido em Portugal nos anos 70 do século XX, através da criação de "instituições e estruturas onde as preocupações ambientais se vão equacionando em termos de intervenção pública", mantendo-se ainda, no entanto, um sistema de

\section{Casa principal (esquerda) / Casa de arrumos (direita) ${ }^{28}$}
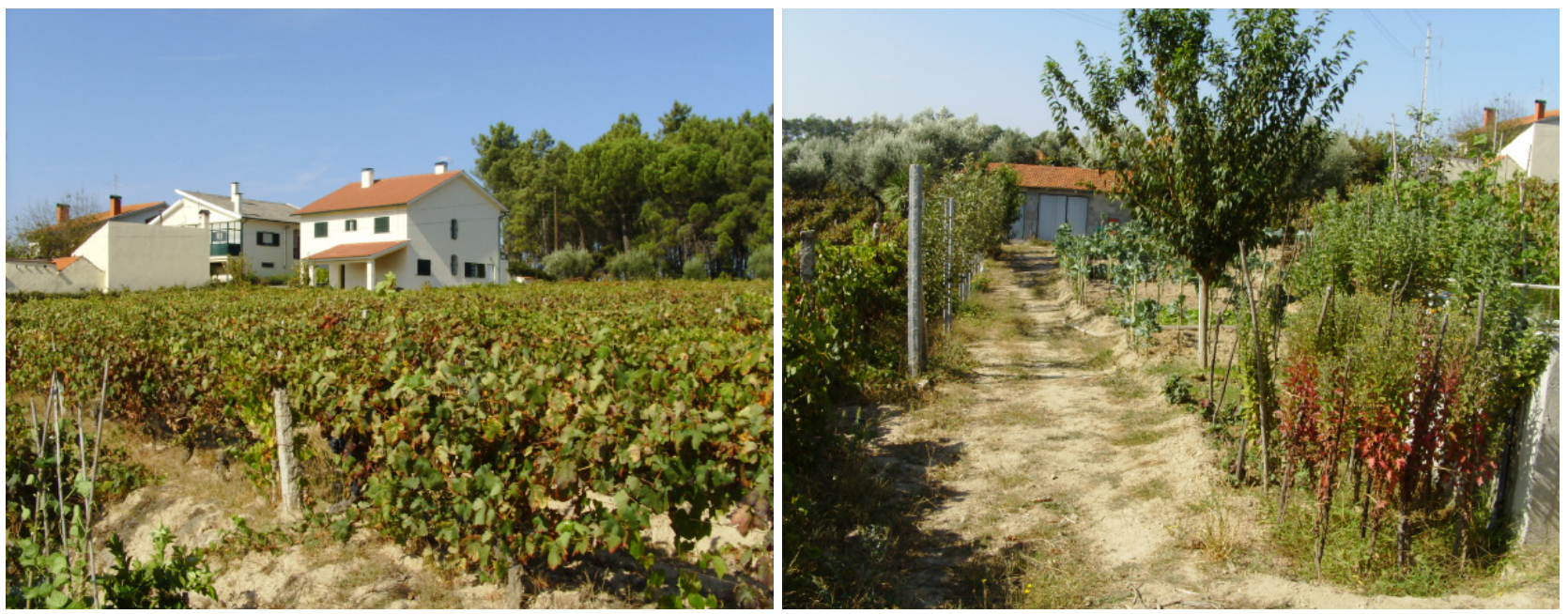

ensino pouco aberto a esta nova realidade mas que aceitava no seu seio "algumas mudanças" e permitia "novas dinâmicas de trabalho, muitas delas evidenciando a existência de conteúdos e metodologias multidisciplinares, onde o ambiente já tinha algum peso educativo" (PALMA, 2006, p. 8).

Durante a socialização primária as estruturas sociais tiveram uma enorme influência na minha modelação e interiorização de valores e oportunidades de vida e, naturalmente, a minha ação individual foi totalmente condicionada pela influência dessas estruturas, que determinavam o bem e o mal, o belo e o feio, o correto e o incorreto, o que fazer e o que não fazer. O principal agente de socialização no seio dessas estruturas era a família, mas também essa refletia as normas morais e hierárquicas da comunidade, o que ainda hoje acontece em comunidades pequenas e isoladas de matriz rural do interior de Portugal.

No conjunto das estruturas que me eram próprias, onde fui integrado durante a socialização primária, o meu poder não existia, ou melhor, estava subordinado a um poder maior, ancestral e consuetudinário, às normas morais e hierárquicas da comunidade. Não existia um padrão ou uma estrutura de relações entre instituições sociais, tais como mercados, classes ou fações políticas (Wilson et al., 2012, p. 155), mas existia um padrão de relações com três estruturas basilares da comunidade: família (casa familiar), igreja/religião (Católica) e grupo laboral (que atuava como classe social). Estes eram os três agentes de socialização determinantes para a vida da comunidade.

Estes três agentes de socialização constituem-se de regras de comportamento, como normas morais e hierárquicas, necessárias à organização social da comunidade, mas não comportam preo-

28 Fotografias capturadas em setembro de 2009, em Carvalhal Redondo (Viseu/Portugal). Do lado esquerdo, está a casa principal e o terreno agrícola para produção mercantil (vinho), e do lado direito, está a casa de arrumos e o terreno agrícola para produção doméstica (cereais, frutas, legumes e diverso gado, como as galinhas, os porcos, as cabras, entre outros). 
cupações ambientais, muito menos com a problemática das alterações climáticas. A Igreja Católica postulava e continua a postular valores seculares em torno dos sete sacramentos: batismo, confissão, crisma, sagrado matrimónio, ordem e unção dos enfermos, e procura respeitar a cultura e a tradição dos seus fiéis. A família vivia segundo os dogmas da Igreja, e deve participar unida na eucaristia dominical, bem como em outras atividades religiosas, considerando que os sacramentos eram uma parte integrante e inalienável da vida de cada católico e fundamentais para a sua salvação.

A Igreja e a família são dois agentes de socialização indissociáveis. Ambos proclamam a necessidade de fazer o bem (boas ações), a necessidade de ajudar o próximo, de respeitar a Deus, de ter uma vida honrada, honesta e livre de pecado, mesmo que na pobreza. A Igreja defende que a vida humana deve ser regulada por critérios não materiais, como a felicidade e a harmonia, e não pela riqueza material, proporcionando de forma fortuita um pensamento amigo da causa ambiental. Não Cultura tradicional - sementeira da batata - cultura preparada para rega a rego ${ }^{29}$
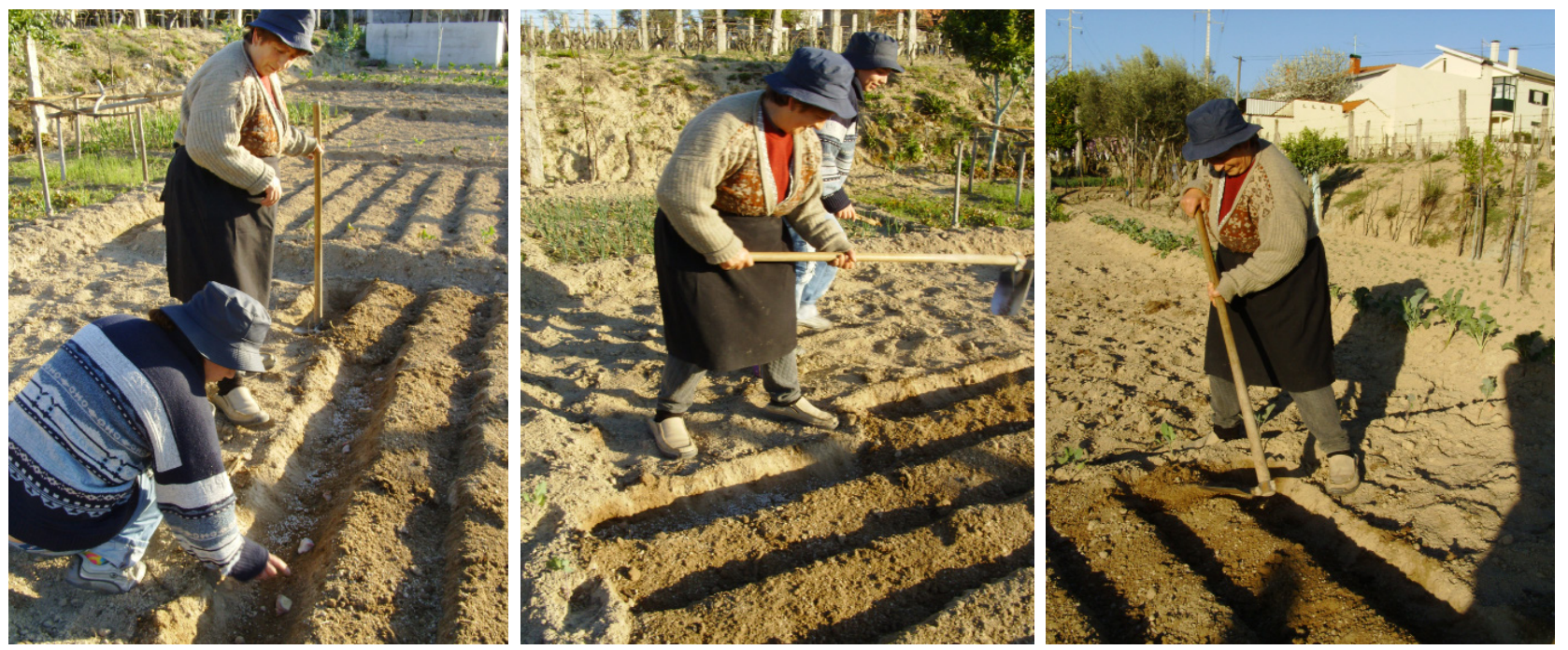

Cultura tradicional - viticultura - apanha de uvas por ajuda ${ }^{30}$
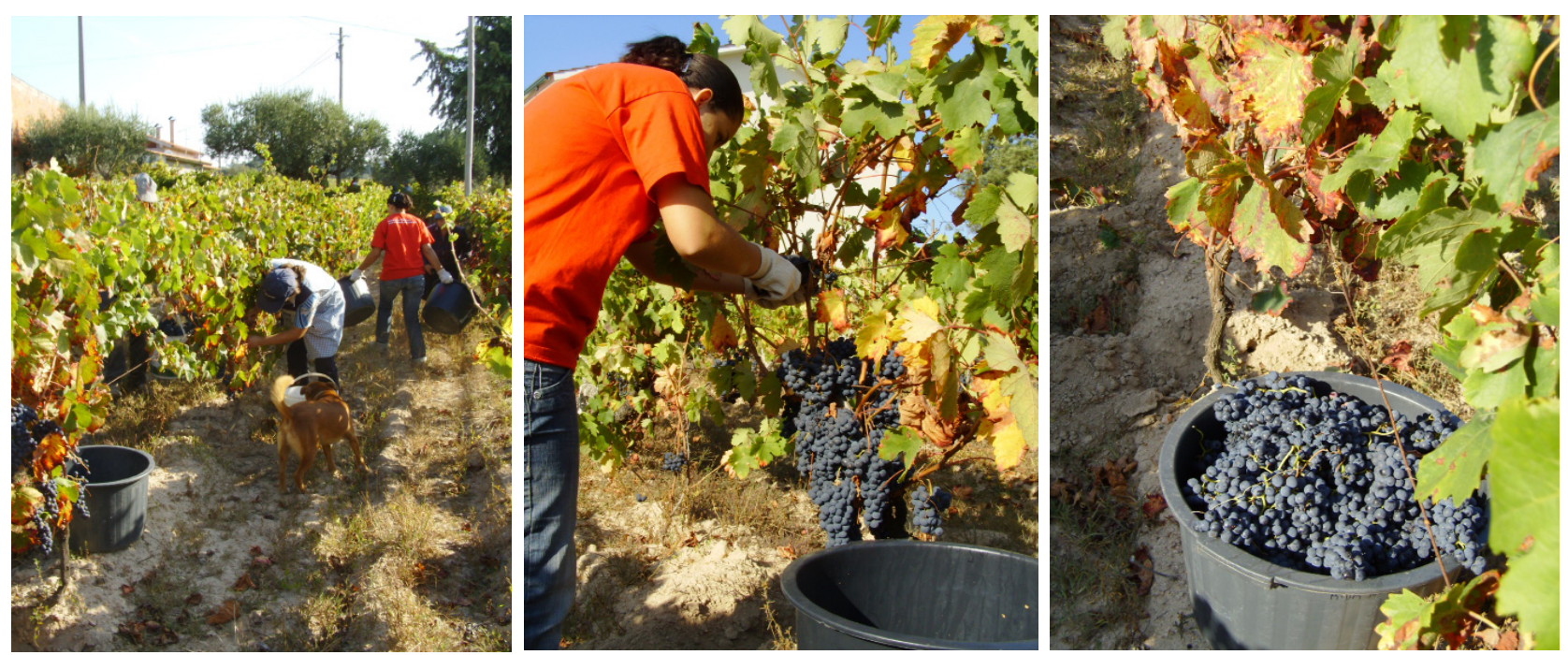

existe uma teologia da prosperidade, uma vez que essa surgiu recentemente com o pentecostalismo e o neopentecostalismo, designados de movimentos religiosos de revitalização (MARIANO, 1996, 1999). É também preciso referir que esta organização social encontrava refúgio na ideologia do Estado Novo - "Deus, Pátria e Família", a trilogia da educação nacional (TORGAL, 2009, p. 426). O grupo

29 Fotografias capturadas em setembro de 2009, em Carvalhal Redondo (Viseu/Portugal).

30 Fotografias capturadas em finais de setembro de 2009, em Carvalhal Redondo (Viseu/Portugal). Na primeira foto, da esquerda para a direita, o guardião da família: o cão "Sultão". 
laboral, equiparado a um grupo social, era constituído por elementos que trabalhavam os campos e faziam produções agrícolas de culturas tradicionais, como a vinha, o azeite, o cereal, as batatas e a horticultura para subsistência. Agricultava-se maioritariamente vinhas, porque o vinho oferecia maior lucro no processo mercantil (isto até ao início do século XXI). As imagens seguintes são elucidativas do tipo e forma de produção.

Cultura tradicional - viticultura - transporte de uvas em balceiros plásticos de $40 \mathrm{Kg}$ (esquerda) e confeção do vinho em vasilha plástica de 400 lt (direita) ${ }^{31}$
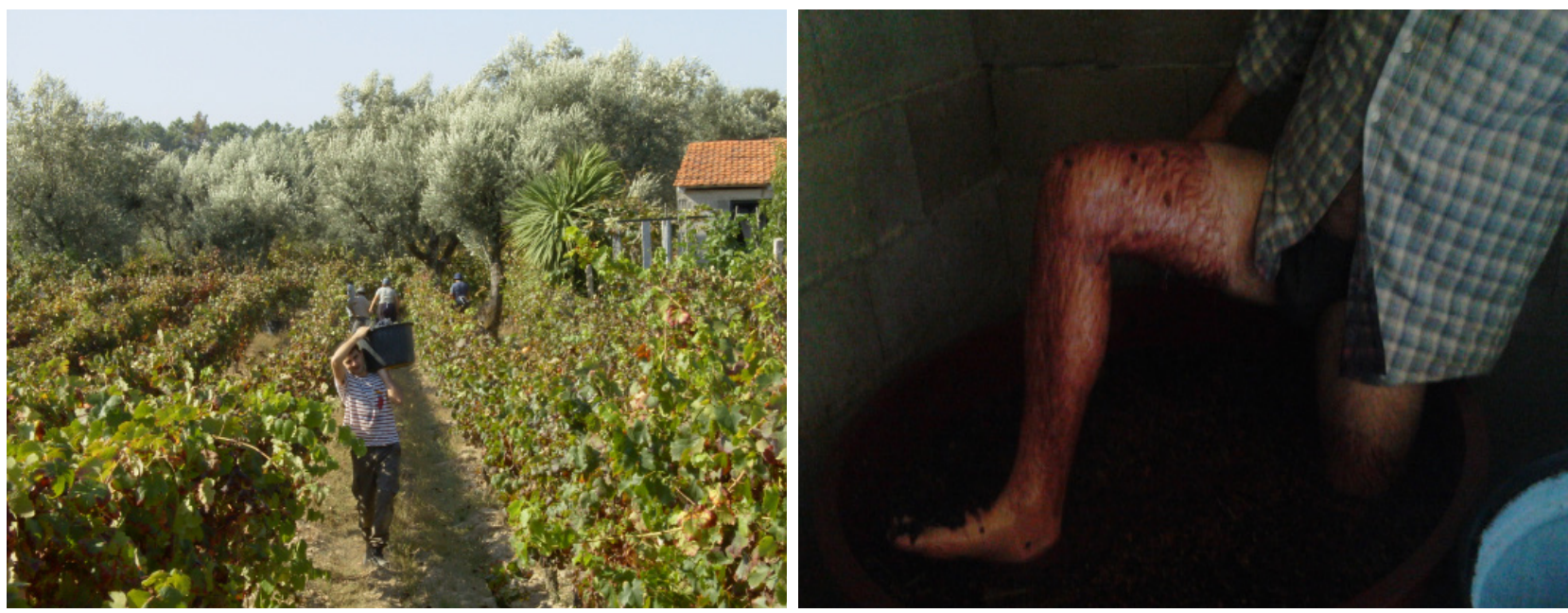

Cultura tradicional - horticultura - preparada para rega a rego ${ }^{32}$
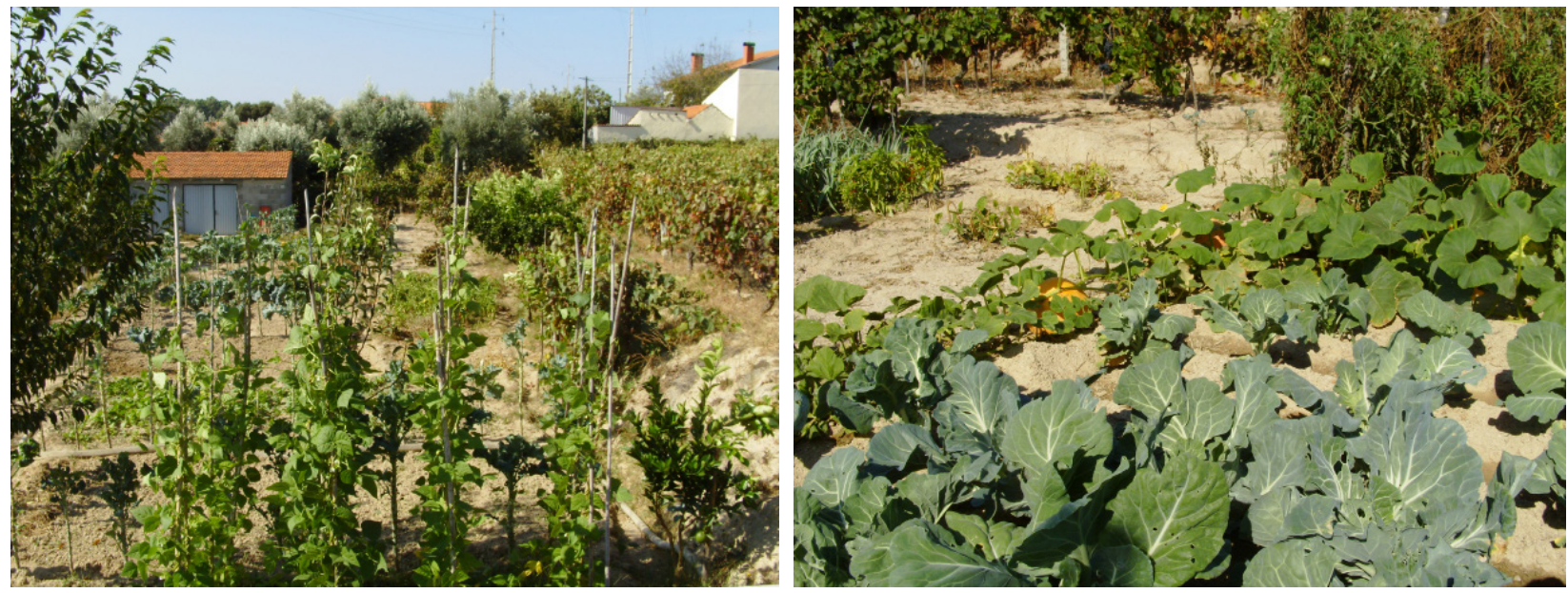

Durante a minha socialização primária não existiu qualquer interação pessoal com a estrutura que tenha influenciado a minha atitude perante as alterações climáticas, nem qualquer ação individual (agência). O que é negativo, porque, como vimos, é neste estágio que as crianças aprendem e interiorizam a linguagem, as regras básicas da sociedade, a moral e os modelos comportamentais do grupo a que pertencem. A socialização primária tem um valor primordial para o indivíduo, e deixa marcas muito profundas em toda a sua vida, porque é aí que se constrói o primeiro mundo do indivíduo. É nesta fase que a criança deve ser iniciada às questões do desenvolvimento sustentável, nas várias vertentes, nomeadamente para a problemática das alterações climáticas. Com rigor, os efeitos das emissões de gases poluentes continuam a ser um assunto desconhecido para a generalidade das pessoas que habitam a minha terra natal, no total de 558 habitantes, algo envelhecidos, segundo os censos da população de

31 Fotografias capturadas em finais de setembro de 2009, em Carvalhal Redondo (Viseu/Portugal).

32 Fotografias capturadas em janeiro de 2009, em Carvalhal Redondo (Viseu/Portugal). 
2011. É uma situação que "urge ajustamento"...

Durante a socialização secundária, ao contrário do que se verificou na socialização primária, a minha interação pessoal com a estrutura da sociedade e ação individual levou à compreensão de um novo um conceito - desenvolvimento sustentável - que por sua vez levou ao conhecimento da problemática das alterações climáticas. Para isso foi determinante a deslocação do espaço rural interior, local de nascimento, para um espaço urbano litoral, local de formação, de trabalho e residência (Lisboa), onde recebi influências provenientes de muitos agentes de socialização, mas sobretudo do grupo laboral, do grupo de amigos, do grupo académico e ainda, mas em menor intensidade, da comunicação social e da internet.

Fazendo a retrospetiva, a socialização secundária representa todo e qualquer processo subsequente (à socialização primária) que introduz um indivíduo já socializado em novos setores do mundo objetivo da sociedade, o que pode acontecer de diversas formas, através da imigração, do êxodo rural, da entrada no mercado de trabalho, ou saída (ex. desemprego), da mudança do estado civil, do cumprimento de penas civis ou penais (ex. prisão), da formação académica ou profissional, da prestação de serviço em causas filantrópicas, entre outros. A mudança leva o individuo a uma nova aprendizagem - de valores, regras sociais, normas morais e hierarquias (relações de poder) - necessária para a interiorização da cultura do novo grupo de pertença, ou ainda, à adoção de outros mecanismos de socialização, através da imitação, que consiste na reprodução dos comportamentos observados, ou da identificação, que se processa quando o indivíduo se reconhece/identifica com uma pessoa ou realidade, da qual se aproxima, progressivamente, acabando por adquirir os mesmos princípios e comportamentos. Como regra, toda a mudança comporta uma forte carga de agência.

No meu caso verificou-se uma mudança, após estar socializado, o êxodo rural. A saída da terra natal, uma sociedade ainda com grande força de valores tradicionais, para uma sociedade urbana, muito heterogénea e diversificada, que oferece maiores e melhores oportunidade de vida, realça a questão da agência, porque, perante as normas e hierarquias de uma sociedade tradicional, neste caso castradora de tudo o que é novidade e empreendedorismo, tive a capacidade necessária para pensar e agir de forma independente, desenvolver o sentido crítico e influenciar os acontecimentos. Ou seja, o comportamento pessoal e as oportunidades de vida foram determinados pela agência, pela capacidade de determinar a própria trajetória, e não por influências negativas emanadas da estrutura. Isto é visível no abandono da zona de conforto (saída da sociedade de nascimento), na qual sentia que tinha um lugar, um nome, uma característica, uma posição, para procurar alterar o rumo, perseguindo o ditado: eu não escolhi o que sou mas posso escolher o que quero ser!!!

Nessa mudança (por via do êxodo rural) ocorreram vários processos que potenciaram a renovação dos valores de base, ou seja, dos referenciais originários da socialização primária. Foram três os principais agentes de socialização. Primeiro, o grupo académico, seja através da formação académica, onde foi possível ter contacto com as questões ambientais, nas várias vertentes, e adquirir maior competência investigativa e crítica, seja através de formação profissional, como o IMOOC "Alterações Climáticas: o contexto das experiências de vida" , um curso aberto massivo online que permitiu o melhor conhecimento da problemática das alterações climáticas, base do presente trabalho. Segundo, o grupo de amigos, de diversas origens geográficas e diferentes condições sociais, e com gostos e pensamentos diversificados, génese da nova aprendizagem. Este grupo tem suporte na Universidade, uma vez que foi o grupo de pertença após a mudança. É formado por colegas de várias áreas científicas. Permite uma grande aprendizagem, mas também abre espaço para ensinar: "o objetivo é aprender e ensinar entre colegas". Terceiro, o grupo laboral, onde existiu aprendizagem para que fosse possível a inclusão, mas trata-se de uma aprendizagem meramente profissional. O grupo laboral, que deveria ter um sentido de responsabilidade para com as questões ambientais, pela profissão e setor de atividade (Administração Pública), apresenta-se profundamente desconhecedor e desinteressado da problemática da sustentabilidade, com demasiados vícios e pouca vontade para inovar ou fazer diferente.

A aprendizagem também ocorreu pela comunicação social (ex. periódicos gratuitos, como o Metro e o Destaque), através de ações de informação que ocorrem diariamente (o que não acontece no espaço interior rural), e pela internet (e redes sociais), o maior conglomerado de redes de comu-

33 Miller (1999, p. 355) define várias armadilhas mentais, a saber: "pessimismo derrotista”, o "otimismo tecnológico cego", o "fatalismo", a "extrapolação para o infinito", a "paralisia pela análise" e a "fé em respostas fáceis". 
nicação à escala mundial, que facilita o acesso à informação em tempo real e constitui a base da "aldeia global", mas que ainda não é um recurso ao alcance da maior parte das famílias que residem no interior rural, sobretudo das que, ainda no ativo, apenas dispõem do rendimento proveniente da agricultura de subsistência e fazem a sua vida depender exclusivamente da força do seu trabalho, ou das que encontram na sua reforma, na maior parte das vezes inferior ao salário mínimo nacional ( $€$ 485 em 2014), a única fonte de subsistência.

Com base na aprendizagem junto dos agentes de socialização, e graças à minha agência, foi possível solidificar argumentos e transformar as questões ambientais num assunto de referência, o que permitiu influenciar a organização da sociedade na sua atitude face às alterações climáticas, e impediu a estrutura da sociedade ou a ação individual ou coletiva dos indivíduos que a compõem de determinar ou influenciar as minhas oportunidades de vida.

Como foi possível intervir de forma eficaz na estrutura da sociedade? Essa intervenção só foi possível no espaço urbano, e não no espaço rural, apesar de ser o local de nascimento. É muito difícil influenciar e alterar a estrutura social num espaço interior rural, constituído por cidadãos maioritariamente de idade avançada. O capital social formado em redes com normas, com relações baseadas na cooperação, confiança e reciprocidade altruísta (PORTES, 2000; PUTNAM, 2002), condiciona a interferência externa. É muito complicado explicar a um agricultor tradicional que é errado fazer a rega por rego, justificando que é mais ecológico e económico fazer a rega com recurso ao sistema de rega gota-a-gota. A idade é um "posto", reflete poder, e as pessoas de maior idade são as mais sábias (uma espécie de anciãos). Estaremos, pois, ao nível das armadilhas mentais de que nos fala Miller $(1999)^{33}$, em posição de acrescentar uma outra, a "confiança excessiva", que impede um indivíduo de aprender aquilo que ele acha que já sabe. Como diz o ditado, "o ser humano deve fugir da confiança excessiva para não se transformar num mísero deslumbrado. Deve desconfiar de si mesmo, do que é, do que quer ser."

Quando uma pessoa que tenta ensinar é considerada parte integrante dessa estrutura social, isso não significa uma mais-valia, pelo contrário, é um elemento depreciativo, porque é dada maior importância ao que é de fora. O velho ditado é real: "prata da casa não faz milagres". No oposto, a estrutura da sociedade urbana "des"personifica, reduz a visibilidade de um cidadão comum, sobretudo quando este vem de fora. Iste é o resultado mais notado no início da mudança, mas apresenta vantagens, porque, com boa agência, torna-se mais fácil desenvolver ou participar em ações de consciencialização para o desenvolvimento sustentável e para as questões do aquecimento global.

A aprendizagem adquirida através da socialização secundária, principalmente no grupo académico, permitiu-me introduzir as preocupações ambientais nos novos grupos de pertença pessoal e profissional. Nestes grupos procuro sistematicamente sensibilizar os indivíduos para o comércio justo e o consumo sustentável, para a necessidade de fazer uma vida não material, com base numa perspetiva de felicidade (ZIDANŠEK, 2007), e para a necessidade de adotar hábitos e práticas sustentáveis, reduzindo a pegada ambiental e colaborando com o meio ambiente local e global, através de pequenas mudanças fáceis de aplicar no quotidiano, determinantes para assegurar o futuro das gerações vindouras (BRUNDTLAND, 1987). Esclareço que um modelo de vida consciente/sustentável, em harmonia com o cosmos, não passa por deixar de consumir e ou por abdicar de condições de vida, ao ponto de voltar ao "tempo das cavernas", mas por consumir produtos mais duráveis e ecológicos na quantidade suficiente (planeando a lista de compras, evitando gastos desnecessários, desperdício de alimentos e de energia), de forma racional, avaliando antes de comprar os constituintes dos produtos e os impactos gerados com o tratamento final (abandono, aterro, valorização, etc.).

A capacitação ocorrida por via de processos de socialização secundários, diametralmente oposta à verificada na infância, condicionado que estava pela estrutura da sociedade, fez com que passasse de uma posição de submissão, de não aprendizagem ou evolução, para uma situação de inovação e grande agência, influenciando o grupo de amigos, pessoal e profissional.

\section{NOTA DE REFLEXÃO FINAL}

Os indivíduos estão cada vez mais conhecedores da ciência das alterações climáticas, e sabemos que o conhecimento das causas do aquecimento global é "um poderoso preditor de intenções comportamentais", quando se acredita que as "alterações climáticas vão acontecer e ter consequências 
negativas" (O'CONNOR et al., 1999, p. 461).

No entanto, talvez pela volatilidade da vida, diametralmente oposta à variabilidade natural do clima (HANSEN et al., 2012, p. 1), não existe uma relação direta e efetiva entre a perceção do perigo e a predisposição para alterar comportamentos (O'CONNOR et al., 1999), com vista a alteração do paradigma dominante. Acresce que os indivíduos têm uma consciência ambiental individualista, e agem de forma reativa, pelo que, para estes, as alterações climáticas afiguram-se como um problema longínquo que, mesmo a confirma-se, a tecnologia poderá resolver.

Mesmo quando existe vontade de mudar, muitas vezes falta a perseverança e o espírito de sacrifício, e as iniciativas resumem-se a comportamentos pontuais e seletivos, não estruturais. Por exemplo, um indivíduo pode apresentar uma elevada predisposição para acolher na sua casa (ou apartamento) sistemas de "climatização passiva" (de ventilação, aquecimento e arrefecimento) e, simultaneamente, ter uma reduzida predisposição para a partilha do automóvel nas deslocações pendulares (que permite maximizar a capacidade da viatura individual), ou para a utilização de transportes públicos, como sabemos, um fator importante para combater os efeitos das alterações climáticas ( $\mathrm{O}^{\prime} \mathrm{CONNOR}$ et al., 1999, p. 464).

Esta agência, mais vulgar do que é desejável, reflete um indivíduo ainda a viver no paradigma consumista, que resume as suas preocupações ambientais a um investimento em tecnologia (capaz de mitigar as emissões). Mas, se buscamos um mundo justo, esforços e sacrifícios têm de ser repartidos por todos, e todos temos de abdicar de parte do conforto materialista. Comportamento bem caracterizado nas armadilhas mentais de Miller (1999), nomeadamente: (i) o pessimismo derrotista, visível em expressões "não se justifica" ou "não vale a pena"; (ii) a extrapolação para o infinito, percetível em expressões como "fazer isto não muda nada", ou seja, nem vale a pena tentar; e (iii) também o otimismo tecnológico cego, ao acreditar que, abdicando dos nossos deveres, poderá a ciência e tecnologia dar resposta a todos os nossos problemas.

É importante abordar as causas do aquecimento global, e alertar para a premente necessidade de mudança de comportamentos, mitigando a inércia instalada. Nunca será demais escrever sobre este assunto. Aliás, não haverá maior erro do que não fazer nada só porque não podemos fazer muito. Estaríamos a incorrer, nós próprios, nas armadilhas mentais de Miller (1999).

O futuro da humanidade não está determinado, e não tem de ser miserável. É possível mitigar os efeitos da pressão humana sobre o Planeta, e ainda esperar um futuro mais digno e próspero, de harmonia na Terra. Mas, para isso, é necessário fazer as coisas acontecerem (ROBERTS, 2012). Ou seja, isso só é possível se a estrutura social assentar em normas de confiança, colaboração e reciprocidade, se existirem regras e sanções (PORTES, 2000; PUTNAM, 2002), se existir criação de capital social, se desenvolvermos um pensamento crítico, e se tivermos agência.

Do lado da estrutura (com incidência na estrutura política), para que exista uma relação de segurança, legitimidade e confiança, é necessário mais transparência: acesso livre à informação - transparência dos processos decisórios, e imparcialidade. Do lado da agência, a chave passa pela educação e pela consciencialização, acompanhadas de uma grande humildade e vontade de mudar, ainda que com sacrifícios pessoais.

Os agentes de socialização são fundamentais para a interiorização individual de valores e normas ambientais, pelo que a família, escola e grupos de pares, e com um papel cada mais decisivo a internet e os recursos que lhe estão associados, como as redes sociais, devem promover fortemente a educação para o desenvolvimento sustentável.

E muito importante introduzir a criança à problemática da sustentabilidade na socialização primária, altura em que constitui a sua identidade, porque durante a socialização secundária, apesar de ser possível produzir alterações na formulação de conviçcões, é mais complicado alterar a matriz identitária.

No caso de vida que estudámos, própria do autor, após uma socialização primária regrada e dependente da estrutura, que condicionou o seu comportamento e oportunidades de vida, foi possível a reabilitação através da ação individual, na socialização secundária, adotando uma identidade de comprometimento com a causa ambiental, que permitiu receber e transmitir influências à estrutura da sociedade, e à ação individual dos que pertencem aos grupos em que está inserido. Tornou-se, assim, num "micro" agente de socialização para as questões da sustentabilidade, onde se enquadra a problemática das alterações climáticas.

Este ensaio permite-nos concluir o quão importante é a ação individual para um mundo mais 
sustentável e para o combate às alterações climáticas, e releva a importância de cada um de nós para persuadir e capacitar quem está em nosso redor para o desenvolvimento social e a sustentabilidade.

Transmite uma mensagem positiva e otimista muito importante, de que é possível reverter a atual situação de delapidação dos recursos naturais, bastando para isso a colaboração de todos, mesmo daqueles que desconsideram estas questões, uma vez que é sempre possível mudar essa conceção/ posição perante a vida ao longo da socialização secundária.

Mostra-nos uma rara oportunidade de repensar a sociedade, e o rumo que estamos a dar às nossas vidas, e enfatiza que não podemos assumir a posição de observadores. A vida com agência só pode seguir um rumo, o de fazer acontecer (ROBERTS, 2012).

Todos os indivíduos devem a si mesmos e às gerações futuras uma atuação com agência, escorada na felicidade e não em valores materiais (ZIDANŠEK, 2007), e nenhum agente de socialização pode alhear-se da sua obrigação moral de educar e formar para a sustentabilidade.

\section{DICAS PARA UMA ATITUDE AMBIENTAL MAIS RESPONSÁVEL, SIMPLES DE UTI- LIZAR NO QUOTIDIANO, E FÁCEIS DE TRANSMITIR AOS GRUPOS DE PERTENÇA:}

(i) ao grupo de amigos pessoal (esfera privada): utilizar produtos de limpeza biodegradáveis em detrimento dos que comportam fosfatos na sua composição, ou então, utilizar produtos de limpeza caseiros, confecionados à base de sódio, limão e vinagre; a utilização de papel reciclado, que consome menos energia no processo industrial; reduzir ao máximo a utilização de garrafas e sacos de plástico, ou optar por garrafas de vidro e sacos de papel/pano, e quando não for possível substituir, reutilizar tantas vezes quanto possível; utilizar lâmpadas florescentes ou LEDs em detrimento das lâmpadas incandescentes, que consomem mais energia; retirar os aparelhos eletrónicos da tomada ao invés de os deixar em standby, o que permite poupar entre 15 e $40 \%$ de energia; manter o frigorífico afastado de fontes de calor, porque vai precisar de mais energia para compensar o aumento da temperatura; não ter o congelador totalmente preenchido e fazer a descongelação de forma regular, para evitar o excesso gelo que dificulta a circulação do ar frio e faz aumentar o consumo de energia; antes de abrir o frigorífico ou a arca frigorífica, pensar quais os produtos a retirar, para que a porta fique aberta o menos tempo possível; utilizar a ventoinha em vez do aparelho de ar condicionado; utilizar pilhas recarregáveis nos vários equipamentos domésticos (máquina fotográfica, despertador, balança, relógio de parede, etc.); utilizar água morna ou fria para lavar a roupa na máquina e fazer cargas completas, ou, não sendo possível, fazer meias cargas selecionando o modo de meia carga para reduzir o consumo de energia; utilizar o mesmo procedimento para a máquina de lavar a loiça, ou simplesmente não a utilizar, e lavar a loiça à mão; aproveitar o sol e o vento para secar a roupa e não a máquina de secar, que, para além de consumir imensa energia, deixa a roupa mais amassada, tornando mais difícil e morosa a passagem a ferro; substituir os eletrodomésticos avariados por outros com melhor eficiência energética; economizar água em todas as tarefas domésticas, por exemplo, fechando a torneira enquanto se escovam os dentes ou reduzindo o tempo médio de banho; utilizar chuveiro e não fazer banhos de banheira; recolher num recipiente a água fria inicial do chuveiro, enquanto se espera pela água quente; instalar nos pontos de água dos WC válvulas para regular a quantidade de água libertada, sobretudo quando se tem crianças; fazer refeições com alimentos da zona, que não carecem de longo transporte, porque os legumes são mais económicos e consomem-se mais frescos; consumir frutas da época; evitar alimentos congelados e enlatados, que são mais dispendiosos e consomem mais energia na confeção (os enlatados geram mais resíduos); consumir carne vermelha de forma controlada, não ultrapassando 170 gramas/dia, porque esta é responsável pela produção de um dos gases mais nocivos para a camada de ozono: o metano ( $\mathrm{CH} 4)$, ao que acresce o facto de cada quilo de carne vermelha necessitar para a sua produção de 200 litros de água, sendo que cada quilo de carne branca só necessita de 10 litros, e não necessita da mesma quantidade de terreno de pastagens, o que também ajuda a combater a desflorestação; dar preferência aos produtos orgânicos porque respeitam os ciclos de vida dos animais, vegetais e solo, e não contaminam o ambiente; tapar as panelas quando estão ao lume para não perderem calor, e dar preferência à panela de pressão, que confeciona uma refeição de forma mais rápida e económica; fazer a triagem do lixo produzido e depositá-lo no ecoponto, e depositar o óleo das frituras em local próprio para que possa ser valorizado (é um ato de profunda irresponsabilidade despejar este óleo na rede de saneamento básico, porque pode provocar entupimentos e leva à 
poluição das águas e do solo; cada litro de óleo chega a poluir um milhão de litros de água). Quem reside no espaço rural - ou residindo no espaço urbano, habita uma vivenda com área verde - pode fazer a compostagem do material orgânico, reduzindo assim a quantidade de lixo encaminhada para aterros sanitários e, consequentemente, a emissão de metano na atmosfera. Poderá utilizar a matéria orgânica no jardim. Os espaços verdes devem ser regados pela manhã ou pela tarde, mas nunca nas horas de maior calor, para evitar a evaporação da água e os choques térmicos nas plantas (ver Pinto (2004) e Ecosave (2012)).

(ii) ao grupo de amigos do trabalho (esfera pública): desligar as luzes e os equipamentos de climatização e refrigeração sempre que não são necessários; regular o ar condicionado para uma temperatura adequada; isolar o espaço quando o ar condicionado está ligado, para mitigar fugas; identificar e comunicar situações de perda de água nas instalações sanitárias; desligar a luz após utilizada a casa de banho; utilizar copos de cerâmica ou metal para beber água das máquinas de refrigeração (dispensadores), em detrimento do tradicional copo de plástico descartável, que tem uma vida mais curta - note-se que, em termos médios, são necessários 16 copos/dia para suprir a necessidade de uma pessoa de consumir 2 litros de água/dia, um ónus demasiado pesado para o ambiente, pelas emissões de $\mathrm{CO}_{2}$ que decorrem da fabricação, transporte e reciclagem de embalagens, e, quando não são devidamente valorizadas, pelo tempo que demoram a ser decompostas na natureza; desligar o computador em longos períodos de ausência, ou, em períodos de ausência mais reduzidos, coloca-lo em modo de hibernação ou suspensão (existem situações em que os computadores ficam ligados de um dia para o outro); realizar reuniões em videoconferência, o que permite reduzir gastos, evitar o trânsito e reduzir a poluição atmosférica; reaproveitar folhas inutilizadas para rascunho, e fazer a reciclagem do papel; desligar a luz da sala de trabalho nos períodos de ausência; colocar as pilhas utilizadas no mini-pilhão, para que sejam recolhidas em segurança pela sociedade Ecopilhas; realizar passeios a pé pelos jardins da zona no tempo livre da hora de almoço, em detrimento dos passeios a pé pelas lojas dos centros comercias, muitas vezes comprando produtos desnecessários; partilhar informação relativa a ações de sensibilização ambiental, e a projetos e novidades tecnológicas na domótica; utilizar os transportes públicos em detrimento do transporte individual e, quando tal não seja possível, adotar soluções em que várias pessoas possam fazer uso do mesmo transporte particular (ver Pinto (2004) e Ecosave (2012)). Por fim, tratar os outros como gostamos de ser tratados.

\section{REFERÊNCIAS}

ALLAN, R.; SODEN, B. Atmospheric warming and the amplification of precipitation extremes. Science. Vol. $321, \mathrm{n}^{\circ}$ 5895, 2008, p. 1481-1484. DOI: $10.1126 /$ science. 1160787.

ALLEN, T.; THOMAS, A. (ed.). Poverty and Development into the 21st Century. Oxford: Oxford University Press, 2000.

ALMEIDA, J.F. Introdução à Sociologia. Lisboa: Universidade Aberta, 1994.

AMARO, F. Introdução à Sociologia da Família. Lisboa: ISCSP, 2006.

ANDERSON, B. Imagined communities. Reflections on the Origin and Spread of Nathionalism. New York: Gopal Balakrishnan, 1991.

BANURI, T.; OPSCHOOR, H. Climate Change and Sustainable Development. Economic \& Social Affairs. DESA Working Paper No. 56. ST/ESA/2007/DWP/56. New York: ONU, 2007. Disponível em: <http://www.un.org/esa/ desa/papers/2007/wp56_2007.pdf>. Acesso em: 15 jun. 2014.

BARKER, C. Cultural Studies: Theory and Practice. $3^{a}$ ed. London: SAGE Publications, 2008. ISBN: 9781412924153.

BAUD, P.; BOURGEAT, S.; BRAS, C. Dicionário de Geografia. Trad. de Raquel Mota e João Atanásio. ISBN: 972707-248-8. Título Original: Dictionnaire de géographie (1997). Lisboa: Plátano Edições Técnicas, 1999. 
BERGER, P.; BERGER, B. Sociology - A Biographical Approach. 2. ${ }^{a}$ ed. Nova York: Basic Books, 1975, p. 49-69.

BORN, R.H. Rio+20: questões sobre economia verde e governança do desenvolvimento sustentável. São Paulo: Vitae Civilis, 2011. Disponível em: <http://vitaecivilis.org/home/images/stories/Docs/Artigos/Rio20_questoes_sobre_ economia_verde_e_governanca_do_desenvolvimento_sustentavel.pdf>. Acesso em: 18 mai. 2014.

BOURDIEU, P. O poder simbólico. Rio de Janeiro: Bertrand Brasil, 2003.

BOYD, R., SILK, J.B. How Humans Evolved. 4ª Ed. New York: Norton, 2006.

BRUNDTLAND, G.H. (coord.).. Our Common Future. Report of the World Commission on Environment and Development, transmitted to the General Assembly as an Annex to document A/42/427 - Development and International Cooperation: Environment. Oxford University Press. 245p., United Nations, 1987. Disponível em: <http://conspect. nl/pdf/Our_Common_Future-Brundtland_Report_1987.pdf>. Acesso em: 21 mar. 2014.

BULKELEY, H. Cities and Climate Change. ISBN: 978-0-415-59704-3. USA: Routledge, 2013. Disponível em: <http://www.routledge.com/books/details/9780415597050/>. Acesso em: 22 nov. 2013.

CARAPETO, C. (Coord.). Educação ambiental. Lisboa: Universidade Aberta, 1998.

CLASTRES, P. Copérnico e os Selvagens. CLASTRES, P.. A sociedade contra o Estado. Porto: Edições Afrontamento, 1979 , p. 5-24.

COMISSÃO EUROPEIA. Alterações climáticas — De que se trata? Uma introdução para os jovens. ISBN 92-8948919-7. Luxemburgo: Serviço das Publicações Oficiais das Comunidades Europeias, 2006.

CURRY, J. A.; WEBSTER, P. J. Climate Science and the Uncertainty Monster. American Meteorological Society. Vol. 92, n. ${ }^{\circ} 12$, 2011, p. 1667 - 1682. DOI: http://dx.doi.org/10.1175/2011BAMS3139.1.

DECRETO n. ${ }^{\circ}$ 20/93, de 21 de junho de 1993. Aprova, para ratificação, a Convenção Quadro sobre Alterações Climáticas. Diário da República n. ${ }^{\circ}$ 143/93, Série I-A, de 21 de junho de 1993. Disponível em: <http://www.fd.uc.pt/CI/ CEE/pm/LegCE/UN_convencao_sobre_alteracoes_climaticas.htm>. Acesso em: 12 jun. 2014.

DECRETO n. ${ }^{\circ}$ 7/2002, de 25 de março de 2002. Aprova o Protocolo de Quioto à Convenção Quadro das Nações Unidas sobre Alterações Climáticas. Diário da República n. ${ }^{\circ}$ 71, Série I-A, de 25 de março de 2002. Disponível em: <http://www.fd.uc.pt/CI/CEE/pm/LegCE/quioto.pdf>. Acesso em: 12 jun. 2014.

DELICADO, A.; SCHMIDT, L.; GUERREIRO, S.; GOMES C. Pescadores, conhecimento local e mudanças costeiras no litoral Português. Revista de Gestão Costeira Integrada. Vol. 12, n. ${ }^{\circ}$ 4, 2012, p. 437-451. DOI:10.5894/rgci349.

DESCARTES, R. Discours de la Méthode. Pour bien conduire sa raison, et chercher la vérité dans les sciences. Plus La dioptrique. Les Meteores. Et La Geometrie. Qui sont des essais de sete Methode. A Leyde. De IÍmprimerie de Ian Maire. Avec privilege. Paris: Ian Maire, 1637.

DESCARTES, R. Principia Philosophiae. Amsterdam: Ludovic Elzevier, 1644. WITH: Specimina Philosophiae: seu Dissertatio de Methodo recte regendae rationis, \& veritatis in scientiis investigandae: Dioptrice, et Meteora. Ex Gallico translata, \& Ab auctore perlecta, variisque in locis emmendata. Amsterdam: Elzevier, 1644.

DOLAN, A.H.; WALKER, I.J. Understanding vulnerability of coastal communities to climate change related risks. Journal of Coastal Research. Vol. SI39, 2004, p. 1317-1324, West Palm Beach, FL, USA. (Proceedings of the 8th International Coastal Symposium). Disponível em: <http://cip2008.cip-icu.ca/_CMS/Files/dolan.pdf>. Acesso em: 21 jul. 2014.

DUNLAP, R.E.; JACQUES, P.J. Climate Change Denial Books and Conservative Think Tanks: Exploring the Connection. American Behavioral Scientist. Vol. 56, n. ${ }^{\circ}$ 6, 2013, p. 699-731. DOI: 10.1177/0002764213477096. 
ECOSAVE. Guia para a utilização eficiente dos eletrodomésticos. Setúbal: Agência de Energia e Ambiente da Arrábida (ENA), 2012. ISBN: 978-989-97705-0-8.

EICHNER, S. Agency and Media Reception. Experiencing Video Games, Film, and Television. Germany: Springer Fachmedien Wiesbaden, 2014. ISBN: 978-3-658-04672-9. DOI: 10.1007/978-3-658-04673-6.

ELLISON, N.B.; STEINFIELD, C.; LAMPE, C.. The Benefits of Facebook "Friends:" Social Capital and College Students' Use of Online Social Network Sites. Journal of Computer-Mediated Communication. Vol. 12, n. ${ }^{\circ} 4$, 2007, p. 1143 - 1168. DOI: 10.1111/j.1083-6101.2007.00367.x.

GIDDENS, A. Sociologia. 4. ${ }^{\text {a }}$ ed. Lisboa Fundação Gulbenkian, 2004.

GIDDENS, A.; PIERSON, C. Conversations with Anthony Giddens: Making Sense of Modernity. California: Stanford University Press, 1998. ISBN: 978-0804735681.

GRAHAM, C. T.; HARROD, C. Implications of climate change for the fishes of the British Isles. Journal of Fish Biology. Vol. 74, n. ${ }^{\circ}$ 6, 2009, p. 1143-1205. DOI: 10.1111/j.1095-8649.2009.02180.x;

GULATI, R.; SRIVASTAVA, S. Bringing Agency Back into Network Research: Constrained Agency and Network Action. BRASS, D.; LABIANCA, G. (Joe); MEHRA, A.; HALGIN, D.; BORGATTI, S. (ed.). Contemporary Perspectives on Organizational Social Networks (Research in the Sociology of Organizations, Volume 40), Emerald Group Publishing Limited, 2014, p. 73-93. DOI: 10.1108/S0733-558X (2014) 0000040004.

HABERL, H.; FISCHER-KOWALSKI, M.; KRAUSMANN, F.; MARTINEZ-ALIER, J.; WINIWARTER, V. A socio-metabolic transition towards sustainability? Challenges for another Great Transformation. Sustainable Development, vol. 19, n. ${ }^{\circ} 1,2011$, p. 1-14. DOI: 10.1002/sd.410.

HALPERN, D.; GIBBS, J. Social media as a catalyst for online deliberation? Exploring the affordances of Facebook and YouTube for political expression. Computers in Human Behavior. Vol. 29, n. ${ }^{\circ}$ 3, 2013, p. 1159-1168. DOI: 10.1016/j.chb.2012.10.008.

HANSEN, J.; SATO, M.; RUEDY, R. Perception of climate change. 9 p. Proceedings of the National Academy of Sciences of the United States of America (PNAS - Early Edition). DOI: 10.1073/pnas.1205276109.

HEGERL, G.; STOTT, P. From Past to Future Warming. Science. Vol. 343, n. ${ }^{\circ} 6173,2014$, p. 844-845. DOI: 10.1126/ science.1249368.

HOPWOOD, B.; MELLOR, M.; O'BRIEN, G. Sustainable development: mapping different approaches. Sustainable Development. Vol. 13, n. ${ }^{\circ} 1,2005$, p. 38-52. DOI: $10.1002 /$ sd.244. $^{2}$

HOTZ, R.L. Inside an Antarctic time machine. TEDGlobal, 2010. Disponível em: <http://www.ted.com/talks/ lee_hotz_inside_an_antarctic_time_machine>. Acesso em: 15 jun. 2014.

HOWARD, C.A. domesticação das mercadorias: estratégias Waiwai. ALBERT, B.; RAMOS, A.R. (Orgs). Pacificando o branco. Cosmologias do contato no Norte Amazônico. São Paulo: Editora UNESP, 2000, p. 25-60.

IPCC. Appendices. In: Climate Change 2001: Mitigation (Working Group III). Switzerland: IPCC and World Meteorological Organization, 2001, p 689-753. Disponível em: <http://www.ipcc.ch/ipccreports/tar/wg3/index.htm>. Acesso em: 12 jun. 2014.

IPCC. Climate Change 2007: Impacts, Adaptation and Vulnerability. In: PARRY, M.L.; CANZIANI, O.F.; PALUTIKOF, J.P.; LINDEN, P.J.; HANSON, C.E. (Eds.). Contribution of Working Group II to the Fourth Assessment. Report of the Intergovernmental Panel on Climate Change (AR4). ISBN: 978-0521-70597-4. Cambridge, UK: Cambridge University Press, 2007. Disponível em: <http://www.ipcc.ch/pdf/assessment-report/ar4/wg2/ar4_wg2_full_report. pdf>. Acesso em: 9 jun. 2014. 
IPCC. Summary for Policymakers. In: STOCKER, T.F.; QIN, D.; PLATTNER, G.-K.; TIGNOR, M.; ALLEN, S.K.; J. BOSCHUNG, NAUELS, A.; XIA, Y.; BEX, V.; MIDGLEY, P.M. (eds.). Climate Change 2013: The Physical Science Basis. Contribution of Working Group I to the Fifth Assessment Report of the Intergovernmental Panel on Climate Change. 1535 p. Cambridge, United Kingdom and New York, NY, USA: Cambridge University Press, $2013 b$. Disponível em: <http://www.climatechange2013.org/images/report/WG1AR5_ALL_FINAL.pdf>. Acesso em: 15 jun. 2014.

IPCC. Working group i contribution to the IPCC fifth Assessment Report (AR5), "Climate Change 2013: The Physical Science Basis". Final Draft Underlying Scientific-Technical Assessment. Stockholm: IPCC, (26 september) 2013a. Disponível em: <http://www.climatechange2013.org/images/uploads/WGIAR5_WGI-12Doc2b_FinalDraft_All.pdf>. Acesso em: 24 mai. 2014.

KIRCHNER, I.; STENCHIKOV, G.L.; GRAF, H-F.; ROBOCK, A.; ANTUÑA, J.C. Climate model simulation of winter warming and summer cooling following the 1991 Mount Pinatubo volcanic eruption. Journal of Geophysical Research: Atmospheres. Vol. 104, n. ${ }^{\circ}$ D16, 1999, p. 19039-19055. DOI: 10.1029/1999JD900213.

MAGGS, W.W. Warming will alter water resources. Eos, Transactions American Geophysical Union. Vol. 70, n. ${ }^{\circ}$ 5, 1989, p. 67-74. DOI: 10.1029/89EO00041.

MARCATTO, T.I.; LIMA, L.A. Sociedade contemporânea e o protocolo de quioto: o mundo em prol do meio ambiente. CONNEXIO, Revista Eletrônica da Escola de Gestão e Negócios (ISSN 2236-8760). Ano II, n. ${ }^{\circ}$ 2, 2013, p. 41-63. Disponível em: <http://repositorio.unp.br/index.php/connexio/article/view/311/280>. Acesso em: 9 mai. 2014.

MARIANO, R. Neopentecostais: sociologia do novo pentecostalismo no Brasil. São Paulo: Loyola, 1999.

MARIANO, R. Os pentecostais e a teologia da prosperidade. Novos Estudos. São Paulo: CEBRAP, 1996.

MILLER, Jr, T. G. Sustaining the Earth. 4ª Ed. USA: Brooks/Cole Publishing Company, 1999.

MORSS, E. Global Warming Is Here, Getting Worse - What Should We Do?. Global Economic Intersection (Econintersect), 2012. Disponível em: <http://econintersect.com/wordpress/?p=24963>. Acesso em: 15 jun. 2014.

O'CONNOR, R.E.; BORD, R.J.; FISHER, A. Risk Perceptions, General Environmental Beliefs, and Willingness to Address Climate Change. Risk Analysis. Vol. 19, n. ${ }^{\circ} 3,1999$, p. 461-471. DOI: 10.1111/j.1539-6924.1999.tb00421.x.

OLIVEIRA, J. Uma etnologia dos "índios misturados?" Situação colonial, territorialização e fluxos culturais. OLIVEIRA, J. (ed.). A Viagem de Volta: Etnicidade, Política e Reelaboração Cultural no Nordeste Indígena. Rio de Janeiro: Contra Capa/ LACED, 2004, p. 13-42.

OLIVEIRA, R. O Índio e o Mundo dos Brancos. Campinas: Editora Unicamp, 1994.

PALMA, J. Manual de práticas ambientais para o ensino básico. 2ª ed. Canelas: Gailivro, 2006.

PINTO, F. Poupar mais, poupar menos, guia prático de acção ecológica. Porto: Nova Gaia, 2004. ISBN: 972-712-3570 .

PORTES, A. Capital Social: origens e aplicações na sociologia contemporânea. Sociologia, problemas e práticas, n. $^{\circ}$ 33, 2000, p. 133-158.

PUTNAM, R. Comunidade e democracia: a experiencia da Itália moderna. Rio de Janeiro: FGV, 2002.

RECUERO, R.C. Um estudo do Capital Social gerado a partir de Redes Sociais no Orkut e nos Weblogs. Rio Alegre: Universidade Católica de Pelotas, 2005. Trabalho apresentado na Compós 2005, no GT de Tecnologias da Informação e da Comunicação. Disponível em: <http://www.ufrgs.br/limc/PDFs/recuerocompos.pdf>. Acesso em: 10 mai. 2014. 
RIBEIRO, D. Os Índios e a Civilização. A integração das populações indígenas no Brasil Moderno, $7^{\mathrm{a}}$ ed. Brasil: Companhia das Letras, 1996.

ROBERTS, D. Climate change is simple. TEDx, The Evergreen State College, 2012. Disponível em: <https://www. youtube.com/watch?v=A7ktYbVwr90>. Acesso em: 15 jun. 2014.

ROCKSTRÖM, J.; STEFFEN, W.; NOONE, K.; PERSSON, Â.; CHAPIN, F.S.; LAMBIN, III, E.; LENTON, T.M.; SCHEFFER, M.; FOLKE, C.; SCHELLNHUBER, H.; NYKVIST, B.; WIT, C.A. de; HUGHES, T.; Van Der LEEUW, S.; RODHE, H.; SÖRLIN, S.; SNYDER, P.K.; COSTANZA, R.; SVEDIN, U.; FALKENMARK, M.; KARLBERG, L.; CORELL, R.W.; FABRY, V.J.; HANSEN, J.; WALKER, B.; LIVERMAN, D.; RICHARDSON, K.; CRUTZEN, P.; FOLEY, J. Planetary boundaries:exploring the safe operating space for humanity. Ecology and Society. Vol. 14, n. ${ }^{\circ}$ 2, art. 32, 2009. Disponível em: <http://www.ecologyandsociety.org/vol14/iss2/art32/>. Acesso em: 15 jun. 2014.

ROLLNICK, R.; NAUDIN, T.. UN-Habitat Annual Report 2010. ISBN: 978-92-1-132336-8. Nairobi: UNON Publishing Services Section, 2011.

ROSA, R.; MARTINS, F.E.; GASPERI, B.L.; MONTICELLI, M.; SIEBERT, E.R.C.; MARTINS, N.M. Mãe e filho: os primeiros laços de aproximação. Escola Anna Nery Revista de Enfermagem (ISSN: 2177-9465). Vol. 14, n. ${ }^{\circ} 1,2010$, p. 105-12. Disponível em: <http://www.scielo.br/pdf/ean/v14n1/v14n1a16>. Acesso em: 12 mai. 2014.

SAMSON, J.; BERTEAUX, D.; MCGILL, B.J.; HUMPHRIES, M.M. Geographic disparities and moral hazards in the predicted impacts of climate change on human populations. Global Ecology and Biogeography. Vol. 20, n. ${ }^{\circ} 4,2011$, p. 532-544. DOI: 10.1111/j.1466-8238.2010.00632.x.

SANTOS, F.D. A Física das Alterações climáticas. Gazeta da Física. Vol. 30, n. ${ }^{\circ}$ 1, 2007, p. 48-57. Disponível em: $<$ http://nautilus.fis.uc.pt/gazeta/revistas/30_1/vol30_fasc1_Art06.pdf>. Acesso em: 15 jun. 2014.

SANTOS, M.P.N. As novas dinâmicas da sustentabilidade urbana em territórios de pobreza e exclusão social: o caso da Cova da Moura. Revista INVI. Vol. 29, n. ${ }^{\circ}$ 81, 2014. DOI: 10.4067/invi.v0i0.777 (no prelo).

SAUNDERS, M.; LEA, A. Large contribution of sea surface warming to recent increase in Atlantic hurricane activity. Nature. Vol. 451, 2008, p. 557-560. DOI: 10.1038/nature06422.

SMITHM, M.D. The ecological role of climate extremes: current understanding and future prospects. Journal of Ecology. Vol. 99, n. ${ }^{\circ} 3$, 2011, p. 651-655. DOI: 10.1111/j.1365-2745.2011.01833.x;

SOROMENHO-MARQUES, V. Alterações climáticas: a crise que não sabemos pensar 3 - As alterações climáticas como problema político. Lisboa: Conferência na Culturgest, 2012a. Disponível em: <http://vimeo.com/42833976> . Acesso em: 21 mai. 2014.

SOROMENHO-MARQUES, V. Alterações climáticas: a crise que não sabemos pensar 4 - As alterações climáticas e o enigma do nosso futuro comum. Lisboa: Conferência na Culturgest, 2012b. Disponível em: <http://vimeo. com/43423538>. Acesso em: 21 mai. 2014.

SOROMENHO-MARQUES, V. Alterações climáticas: a crise que não sabemos pensar 1 - A construção científica das alterações climáticas. Lisboa: Conferência na Culturgest, 2012c. Disponível em: <http://vimeo.com/43423538>. Acesso em: 20 mai. 2014.

SOROMENHO-MARQUES, V. Four Principles regarding the Bali Road Map From Kyoto to Copenhagen. In: Climate Change and Energy security. 2. ${ }^{a}$ Conferência Internacional sobre Alterações Climáticas e Segurança Energética. ISBN: 978-972-556-497-4. Lisboa: Assembleia da República, 2008, p. 143-154.

SORTE, C.J.B.; IBÁÑEZ, I.; BLUMENTHAL, D.M.; MOLINARI, N.A.; MILLER, L.P.; GROSHOLZ, E.D.; DIEZ, J.M.; D'ANTONIO, C.M.; OLDEN, J.D.; JONES, S.J.; DUKES, J.S. Poised to prosper? A cross-system com- 
parison of climate change effects on native and non-native species performance. Ecology Letters. Vol. 16, n. ${ }^{\circ}$ 2, 2013, p. 261-270. DOI: 10.1111/ele.12017.

STENCHIKOV, G.L.; KIRCHNER, I.; ROBOCK, A.; GRAF, H-F.; ANTUÑA, J.C.; GRAINGER, R.G.; LAMBERT, A.; THOMASON, L. Radiative forcing from the 1991 Mount Pinatubo volcanic eruption. Journal of Geophysical Research: Atmospheres. Vol. 103, n. ${ }^{\circ}$ D12, 1998, p. 13837-13857. DOI: 10.1029/98JD00693.

STONES, R. Structure and Agency. RITZER, G. (ed). Blackwell Encyclopedia of Sociology. Blackwell Publishing, 2007. DOI: $10.1111 /$ b.9781405124331.2007.x.

SUNSTEIN, C.R. The Complex Climate Change Incentives of China and the United States (August 2007). U of Chicago Law \& Economics, Olin Working Paper No. 352; U of Chicago, Public Law Working Paper No. 176. DOI: http://dx.doi.org/10.2139/ssrn.1008598.

SY, A. Special issue on: Accounting for global warming. Critical Perspectives on Accounting. Vol. 19, 2008, p. 431 434. DOI:10.1016/j.cpa.2007.07.002.

TORGAL, L.R. Estados novos, estado novo: ensaios de história política e cultural. Vol. 1. Coimbra: Imprensa da Universidade de Coimbra, 2009.

UNDP. Human Development Report 2007/2008. Fighting climate change: Human solidarity in a divided world. ISBN 978-0-230-54704-9. USA: UNDP, 2007.

UNDP. Human Development Report 2013. The Rise of the South: Human Progress in a Diverse World. ISBN 97892-1-126340-4. USA: UNDP, 2013. Disponível em: <http://www.undp.org/content/dam/undp/library/corporate/ HDR/2013GlobalHDR/English/HDR2013\%20Report\%20English.pdf>. Acesso em: 15 jun. 2014.

UNFCCC. United Nations framework Convention on Climate Change. New York: UNFCCC, 1992. Disponível em: $<$ https://unfccc.int/files/essential_background/background_publications_htmlpdf/application/pdf/conveng.pdf> . Acesso em: 14 jun. 2014.

WEART, S.R. The Carbon Dioxide Greenhouse Effect. 2008. Disponível em: <http://www.aip.org/history/climate/ co2.htm>. Acesso em: 22 mai. 2014.

WILSON, G. et al.. T869 Climate change: from science to lived experience. Module 1: Introduction to climate change in the context of sustainable development. United kingdom: Open University, 2012. Disponível em: < https://repositorioaberto.uab.pt/bitstream/10400.2/2127/1/LECHe_Module1_Textbook_2012.pdf>. Acesso em: 21 jul. 2014.

WOLF, S.G.; SNYDER, M.A.; SYDEMAN, W.J.; DOAK, D.F.; CROLL, D.A. Predicting population consequences of ocean climate change for an ecosystem sentinel, the seabird Cassin's auklet. Global Change Biology. Vol. 16, n. ${ }^{\circ}$, 2010, p. 1923-1935. DOI: 10.1111/j.1365-2486.2010.02194.x;

ZIDANŠEK, A. Sustainable development and happiness in nations. Energy. Vol. 32, n. ${ }^{\circ}$ 6, 2007, p. 891-897. DOI:10.1016/j.energy.2006.09.016.

ZOLINA, O.; SIMMER, C.; GULEV, S.; KOLLET, S. Changing structure of European precipitation: Longer wet periods leading to more abundant rainfalls. Geophysical Research Letters. Vol. 37, L06704, 2010. DOI: 10.1029/2010GL042468. 